\title{
Circulating mediators of remote ischemic preconditioning: search for the missing link between non-lethal ischemia and cardioprotection
}

\author{
Muntasir Billah ${ }^{1,2}$, Anisyah Ridiandries ${ }^{1,2}$, Usaid Allahwala ${ }^{2}$, Harshini Mudaliar ${ }^{1}$, \\ Anthony Dona ${ }^{1}$, Stephen Hunyor ${ }^{1}$, Levon M. Khachigian ${ }^{3}$ and Ravinay Bhindi ${ }^{1,2}$ \\ ${ }^{1}$ Department of Cardiology, Kolling Institute, Northern Sydney Local Health District, St Leonards, NSW, Australia \\ ${ }^{2}$ Sydney Medical School Northern, University of Sydney, Sydney, NSW, Australia \\ ${ }^{3}$ Vascular Biology and Translational Research, School of Medical Sciences, University of New South Wales, Sydney, NSW, Australia \\ Correspondence to: Muntasir Billah, email: billah.muntasir08@gmail.com \\ Keywords: remote preconditioning; cardioprotection; myocardial infarction; ischemia-reperfusion; circulating mediators \\ Received: June 02, $2018 \quad$ Accepted: December 10,2018 Published: January 04, 2019 \\ Copyright: Billah et al. This is an open-access article distributed under the terms of the Creative Commons Attribution License 3.0 \\ (CC BY 3.0), which permits unrestricted use, distribution, and reproduction in any medium, provided the original author and source \\ are credited.
}

\section{ABSTRACT}

Acute myocardial infarction (AMI) is one of the leading causes of mortality and morbidity worldwide. There has been an extensive search for cardioprotective therapies to reduce myocardial ischemia-reperfusion (I/R) injury. Remote ischemic preconditioning (RIPC) is a phenomenon that relies on the body's endogenous protective modalities against I/ $R$ injury. In RIPC, non-lethal brief $I / R$ of one organ or tissue confers protection against subsequent lethal $I / R$ injury in an organ remote to the briefly ischemic organ or tissue. Initially it was believed to be limited to direct myocardial protection, however it soon became apparent that RIPC applied to other organs such as kidney, liver, intestine, skeletal muscle can reduce myocardial infarct size. Intriguing discoveries have been made in extending the concept of RIPC to other organs than the heart. Over the years, the underlying mechanisms of RIPC have been widely sought and discussed. The involvement of blood-borne factors as mediators of RIPC has been suggested by a number of research groups. The main purpose of this review article is to summarize the possible circulating mediators of RIPC, and recent studies to establish the clinical efficacy of these mediators in cardioprotection from lethal I/R injury.

\section{INTRODUCTION}

Impaired coronary circulation during myocardial ischemia leads to lethal hypoxic injury. Rapid restoration of coronary blood flow through either thrombolytic therapy or percutaneous coronary intervention (PCI) is essential to limiting myocardial infarction (MI) size, preserving left ventricular (LV) ejection fraction and preventing LV remodeling. Revascularization via either thrombolytic therapy or PCI reduces the mortality rate of patients suffering a heart attack by almost $50 \%$ [1]. Paradoxically, restoration of oxygenated blood to the ischemic heart after revascularization aggravates tissue damage, a phenomenon known as ischemia reperfusion (I/R) injury [2] considered to be mediated by calcium overload, oxidative stress and inflammation [3]. This prompted a search for novel therapeutic strategies to protect the heart against $\mathrm{I} / \mathrm{R}$ injury to improve clinical outcomes of the patients presenting with MI.

The current therapeutic strategy to $I / R$ injury is ischemic conditioning, which is an endogenous approach to protect the heart against acute $\mathrm{I} / \mathrm{R}$ injury. Murry et al. used a canine model to provide the first demonstration that brief episodes of non-lethal $\mathrm{I} / \mathrm{R}$ to the heart prior to sustained ischemia can dramatically reduce MI size, an endogenous cardioprotective phenomenon termed 
ischemic preconditioning (IPC) [4]. IPC has been well studied and found to reduce $\mathrm{I} / \mathrm{R}$ associated damage to other organs including the lung [5], kidney [6], liver [7], skeletal muscle [8], intestine [9], brain [10] and improve post-operative recovery from cardiac surgeries [11]. The potential clinical application of IPC is restricted to elective cardiac surgeries, where the timing of ischemic insult is well controlled. However, patients with acute myocardial infarction (AMI) presented with blocked coronary arteries, making it impossible to precondition the heart. Ischemic postconditioning (IPost), where a non-lethal I/R is performed to the heart by interrupting the PCI-induced reperfusion, delivers a similar outcome to IPC making it a better strategy to treat patients with AMI. Both IPC and IPost require interventional approaches, which limit application in clinical settings. In contrast to directly preconditioning the target organ, Przyklenk and Whittaker in 1993 made the intriguing discovery that preconditioning the heart does not limit its efficacy to the perfused area of the coronary artery, but was extended to remote myocardial tissue [12]. Similarly, Liauw et al. showed that skeletal muscle can be protected against $\mathrm{I} / \mathrm{R}$ by preconditioning the contralateral skeletal muscle [13]. This discovery facilitated the extension of preconditioning techniques to protect other organs beyond the heart. This approach of remotely protecting a target organ through ischemic preconditioning is known as remote ischemic preconditioning (RIPC). A major advance in myocardial RIPC came with the use of skeletal muscle as the origin of RIPC stimulus and brief I/R produced with a tourniquet applied to one of the hind limbs of pig [14]. This lead to a blood pressure measuring cuff around the arm to achieve the RIPC stimulus making it possible to accommodate most of the clinical settings of acute I/R injury. In a non-invasive approach, RIPC has the capacity to protect the organ or tissue whether applied prior to I/R (RIPC), after ischemia but prior to reperfusion (PerC) [15] or during reperfusion (remote ischemic postconditioning, RIPost) [16]. Pryds and colleagues demonstrated the long term effect of RIPC on heart failure patients and reported that though RIPC does not improve left ventricular ejection fraction (LVEF) but reduces blood pressure and NT-proBNP in patients with compensated chronic ischemic heart failure [17] and may reduce the risk of thrombosis by stimulating fibrinolysis [18]. Table 1 summarizes the key clinical trials on the effect of RIPC prior to coronary artery bypass graft (CABG) and PCI. Previous review papers by Hausenloy and Yellon in 2008 [19] and Costa et al. in 2013 [20] discussed the cardioprotective pathways induced by RIPC. The present review focuses on the circulating mediators of RIPC that underpin signal transduction mechanisms from the remote organ to the target organ.

\section{INTER-ORGAN PRECONDITIONING}

The effect of RIPC is not confined to one organ but impacts multiple organs. Similarly, different organs can be used as the RIPC site. Table 2 summarizes the key findings on inter-organ preconditioning studies. Briefly, applying RIPC stimulus to different organs has been shown to protect various target organs from I/R injury. These protective effects include reduced infarct size, decrease arrhythmia, improved lung and liver function (Table 1).

\section{MECHANISMS UNDERLYING RIPC}

The underlying mechanisms through which brief episodes of $\mathrm{I} / \mathrm{R}$ in an organ or tissue transduces a protective signal to a distant organ and renders it resistant to sustained I/R injury is not fully understood. Some studies suggest there is similarity in the mechanistic process of direct preconditioning and RIPC. Based on current knowledge, this can be divided into three major parts: (i) the humoral (ii) the neuronal pathway, and (iii) the systemic pathway (Figure 1). However, whether these pathways independently exert protective effect on the target organ or that crosstalk is involved is not well understood. Table 3 summarizes the major animal studies on the mechanisms of RIPC-induced protection of target organs. The studies focused on the neural, humoral and systemic pathways of RIPC. Apart from Jones et al. [21] these studies applied intermittent I/R as RIPC stimulus. More information may be sourced from the references provided.

\section{Humoral pathway}

Multiple studies support the theory of blood borne mediators as a signal transduction mechanism and the requirement for a period of reperfusion to washout humoral factors generated by RIPC [22], [23]. These protective substances circulate via the bloodstream and upon reaching the target organ bind to respective receptors and activate intracellular signaling pathways. Humoral pathway involvement in RIPC was demonstrated by Konstantinov and colleagues [24]. Denervated donor heart recipient pigs that underwent remote limb preconditioning showed significant reduction of MI size, which provides evidence for the concept of humoralmediated cardioprotection by RIPC. Dickson and colleagues showed for the first time that RIPC could elicit cross species protection [25-27]. These studies explored transfusing blood from preconditioned rabbit hearts and kidneys to a non-preconditioned isolated rabbit heart and showed recovery of the heart from myocardial I/R injury by reducing the infarct size. These authors also showed that coronary effluent from a preconditioned ex-vivo rabbit heart could potentiate the similar infarction limiting effect and improve left ventricle function [28]. Shimizu et al. reported similar cross species protection after using plasma dialysate from remote preconditioned rabbit and human blood to protect ex vivo rabbit heart from I/R injury 
Table 1: Key clinical trials of RIPC

\begin{tabular}{|c|c|c|c|c|}
\hline First author & Nature of trial & $\begin{array}{c}\text { Number of } \\
\text { participants } \\
\text { analyzed (RIPC } \\
\text { / Control) }\end{array}$ & RIPC protocol & Cardioprotection \\
\hline \multicolumn{5}{|c|}{ Coronary artery bypass graft } \\
\hline Hong et al. [218] & $\mathrm{RCT}$ & $35 / 35$ & $\begin{array}{l}4 \text { cycles of } 5 \mathrm{~min} I / R \text { on lower } \\
\text { limb }\end{array}$ & Yes \\
\hline Lucchinetti et al. [214] & $\mathrm{RCT}$ & $27 / 28$ & 4 cycles of $5 \mathrm{~min} \mathrm{I} / \mathrm{R}$ of leg & No \\
\hline Hausenloy et al. [219] & $\mathrm{RCT}$ & $27: 30$ & $\begin{array}{l}3 \text { cycles of } 5 \mathrm{~min} \mathrm{I} / \mathrm{R} \text { of right } \\
\text { upper } \operatorname{limb}\end{array}$ & Yes \\
\hline Candilio et al. [220] & $\mathrm{RCT}$ & $89 / 89$ & $\begin{array}{l}2 \text { cycles of simultaneous } 5 \mathrm{~min} \mathrm{I} / \mathrm{R} \\
\text { on upper arm and upper thigh }\end{array}$ & Yes \\
\hline Venugopal et al. [221] & $\mathrm{RCT}$ & $23 / 22$ & $\begin{array}{l}3 \text { cycles of } 5 \mathrm{~min} \mathrm{I} / \mathrm{R} \text { of right } \\
\text { forearm }\end{array}$ & Yes \\
\hline Hausenloy et al. [215] & Multicenter RCT & $801 / 811$ & 4 cycles of $5 \mathrm{~min} \mathrm{I} / \mathrm{R}$ of upper arm & No \\
\hline Krogstad et al. [216] & $\mathrm{RCT}$ & $45 / 47$ & 3 cycles of $5 \mathrm{~min} \mathrm{I} / \mathrm{R}$ of upper arm & No \\
\hline Hong et al. [222] & $\mathrm{RCT}$ & $644 / 636$ & $\begin{array}{l}4 \text { cycles of } 5 \mathrm{~min} \mathrm{I} / \mathrm{R} \text { of upper limb } \\
\text { as RIPC and } 4 \text { cycles of } 5 \mathrm{~min} \mathrm{I} / \mathrm{R} \\
\text { of upper limb as RIPost }\end{array}$ & No \\
\hline Meybohm et al. [207] & Multicenter RCT & $692 / 693$ & 4 cycles of $5 \mathrm{~min} \mathrm{I} / \mathrm{R}$ of upper arm & No \\
\hline \multicolumn{5}{|c|}{ Percutaneous coronary intervention } \\
\hline Pryds et al.[223] & $\begin{array}{c}\text { Post-hoc analysis of } \\
\text { RCT }\end{array}$ & $166: 167$ & 4 cycles of $5 \mathrm{~min} \mathrm{I} / \mathrm{R}$ of upper arm & Yes \\
\hline Sloth et al. [224] & $\begin{array}{c}\text { Post-hoc analysis of } \\
\text { RCT }\end{array}$ & $71: 68$ & 4 cycles of $5 \mathrm{~min} \mathrm{I} / \mathrm{R}$ of upper arm & Yes \\
\hline Pryds et al. [225] & $\begin{array}{c}\text { Post-hoc analysis of } \\
\text { RCT }\end{array}$ & $71: 68$ & 4 cycles of $5 \mathrm{~min} \mathrm{I} / \mathrm{R}$ of upper arm & Yes \\
\hline Botker et al. [226] & $\mathrm{RCT}$ & $126: 125$ & 4 cycles of $5 \mathrm{~min} \mathrm{I} / \mathrm{R}$ of upper arm & Yes \\
\hline Prasad et al. [217] & $\mathrm{RCT}$ & $47: 48$ & 3 cycles of $3 \mathrm{~min} \mathrm{I} / \mathrm{R}$ of upper arm & No \\
\hline Verouhis et al. [199]. & RCT & $60: 55$ & $\begin{array}{l}1 \text { cycle of } 5 \mathrm{~min} \mathrm{I} / \mathrm{R} \text { of left thigh } \\
\text { before } \mathrm{PCI} \text { and } 4 \text { cycles of } 5 \mathrm{~min} \\
\mathrm{I} / \mathrm{R} \text { of left thigh post reperfusion }\end{array}$ & Neutral \\
\hline
\end{tabular}

Note: RCT: Randomized control trial, I/R: Ischemia-reperfusion.

[29]. These authors also confirmed that the transferrable factors are hydrophobic in nature and $<15 \mathrm{kDa}$ in size. Serejo et al. provided evidence that the humoral factors released from the ischemic preconditioned heart were thermolabile, hydrophobic, $>3.5 \mathrm{kDa}$ and conferred cardioprotection via the activation of protein kinase $\mathrm{C}$ (PKC) [30]. Breivik et al. also reported the presence of $<30 \mathrm{kDa}$ hydrophobic factors in the coronary IPC effluent, which can confer cardioprotection via the PI3K/AKT pathway [31]. Interestingly, proteomic analysis of renal RIPC conducted by Lang and colleagues could not detect any cytoprotective factors larger than $8 \mathrm{kDa}$ [32]. The humoral factors responsible for the RIPC effect on the target organs still remain unclear and investigation into the factors responsible continues. Identifying the potential humoral mediators of RIPC could assist in confirming that the threshold for a RIPC response has been achieved [33].

\section{Neural pathway}

A neural pathway is one that connects one part of the nervous system with another by way of axons. Evidence suggests that intact neural pathway is essential for the remote organ or tissue to convey protective signal to the target organ during the process of RIPC. Denervation of the neural pathway in the remote 
Table 2: Key studies on inter-organ preconditioning

\begin{tabular}{|c|c|c|c|}
\hline Study (RIPC Site) & Species & Target organ & Result \\
\hline \multicolumn{4}{|l|}{ Renal } \\
\hline McClanahan et al. [227] & Rabbit & Heart & $\downarrow$ Infarct size \\
\hline Gho et al. [22] & Rat & Heart & $\downarrow$ Infarct size \\
\hline Verdouw et al. [228] & Pig & Heart & $\downarrow$ Infarct size \\
\hline Pell et al. [229] & Rabbit & Heart & $\downarrow$ Infarct size \\
\hline Takaoka et al.[52] & Rabbit & Heart & $\begin{array}{l}\downarrow \text { Infarct size and improved myocardial energy } \\
\text { metabolism }\end{array}$ \\
\hline Diwan et al. [230] & Rat & Heart & $\begin{array}{l}\text { Conferred cardioprotection by NFkB activation } \\
\text { followed by opening of K(ATP) channels }\end{array}$ \\
\hline Lang et al. [32] & Rat & Heart & $\downarrow$ Infarct size \\
\hline Singh et al. [231] & Rat & Heart & $\begin{array}{l}\downarrow \text { Infarct size and proposed the involvement } \\
\text { of angiotensin AT(1) receptors in renal } \\
\text { preconditioning }\end{array}$ \\
\hline Kant et al. [232] & Rat & Heart & $\begin{array}{l}\text { Reduced myocardial injury through } \\
\text { inhibition of hypoxia inducible factor-prolyl } \\
\text { 4-hydroxylases }\end{array}$ \\
\hline \multicolumn{4}{|l|}{ Small Intestine } \\
\hline Gho et al. [22] & Rat & Heart & $\downarrow$ Infarct size \\
\hline Verdouw et al. [228] & Pig & Heart & $\downarrow$ Infarct size \\
\hline Patel et al. [233] & Rat & Heart & $\downarrow$ Infarct size \\
\hline Heidbreder et al.[234] & Rat & Heart & $\begin{array}{l}\downarrow \text { Infarct size and activated p38 MAPK, ERK } \\
1 / 2 \text { and JNK } 1 / 2 \text { selectively in the intestine but } \\
\text { not in the heart }\end{array}$ \\
\hline \multicolumn{4}{|l|}{ Liver } \\
\hline Ates et al. [235] & Rat & Kidney & $\begin{array}{l}\text { Improved creatine clearance and improvement } \\
\text { in hepatic histopathologic parameters }\end{array}$ \\
\hline Brzozowski et al. [236] & Rat & Gut & Reduced gastric mucosa lesion \\
\hline \multicolumn{4}{|l|}{ Brain } \\
\hline Tapuria et al. [237] & Rat & Liver & $\begin{array}{l}\text { Improved hepatic microcirculation and } \\
\text { reduced hepatic I/R injury. }\end{array}$ \\
\hline \multicolumn{4}{|l|}{ Hind Limb } \\
\hline Oxman et al. [238] & Rat & Heart & Decreased arrhythmias \\
\hline Birnbaum et al.[239] & Rabbit & Heart & Reduced MI size \\
\hline Liauw et al. [13] & Rat & Thigh muscle & Reduced muscle necrosis \\
\hline Kharbanda et al. [14] & Pig & Heart & Reduced MI size \\
\hline Gunaydin et al. [240] & Human & Heart & Enhanced anaerobic glycolysis to protect heart \\
\hline Xia et al. [241] & Sheep & Lung & $\begin{array}{l}\text { Protected lung from repeated coronary artery } \\
\text { occlusion (CAO) and reperfusion mimicking } \\
\text { multi-vessel off-pump coronary artery bypass } \\
\text { (OPCAB) revascularization and decreased } \\
\text { pulmonary vascular resistance }\end{array}$ \\
\hline
\end{tabular}

(Continued) 


\begin{tabular}{|c|c|c|c|}
\hline Study (RIPC Site) & Species & Target organ & Result \\
\hline Addison et al. [242] & Pig & Skeletal muscle & $\begin{array}{l}\text { Protected global skeletal muscle against } \\
\text { infarction }\end{array}$ \\
\hline Kuntscher et al. [243] & Rat & Adipocutaneous flaps & Decreased flap necrosis \\
\hline Kuntscher et al. [244] & Rat & $\begin{array}{l}\text { Cremasteric muscle } \\
\quad \text { flaps }\end{array}$ & Decreased flap necrosis \\
\hline Kuntscher et al. [245] & Rat & $\begin{array}{l}\text { Epigastric } \\
\text { adipocutaneous flaps }\end{array}$ & Decreased flap necrosis \\
\hline Moses et al. [246] & Pig & $\begin{array}{l}\text { Latissimus dorsi (LD) } \\
\text { muscle flaps }\end{array}$ & Decreased flap infarction \\
\hline Wang et al. [247] & Rat & Cremaster flap & Decreased flap necrosis \\
\hline Harkin et al. [248] & Pig & Lung & $\begin{array}{l}\text { Reduced acute remote lung damage against } \\
\text { systemic inflammatory response from limb I/R } \\
\text { injury }\end{array}$ \\
\hline Li et al. [249] & Mice & Heart & $\begin{array}{l}\text { Protected LV function and reduced infarction } \\
\text { size }\end{array}$ \\
\hline Konstantinov et al. [24] & Pig & Heart & $\begin{array}{l}\text { Reduced I/R injury in the brain-dead } \\
\text { donor heart following orthotopic heart } \\
\text { transplantation. }\end{array}$ \\
\hline Chen et al. [250] & Rat & Heart & Reduced infarction size \\
\hline Chen et al. [251] & Rat & Heart & $\begin{array}{l}\text { Reduced infarction size through free radical } \\
\text { pathway }\end{array}$ \\
\hline $\begin{array}{l}\text { Luokogeorgakis et al. } \\
\text { [252] }\end{array}$ & Human & Forearm & Preserved endothelial function in the forearm \\
\hline Waldow et al. [253] & Pig & Lung & $\begin{array}{l}\text { Protected lung function and reduced the } \\
\text { plasma interleukin-1beta level }\end{array}$ \\
\hline Kristiansen et al. [254] & Rat & Heart & $\begin{array}{l}\text { Reduced MI size through a mechanism } \\
\text { involving mitochondrial K(ATP) channels and } \\
\text { improved LV function during reperfusion }\end{array}$ \\
\hline Zhang et al. [255] & Rat & Heart & $\begin{array}{l}\text { Reduced infarction size and I/R-induced } \\
\text { plasma lactate dehydrogenase level }\end{array}$ \\
\hline Dave et al. [256] & Rat & Heart & $\begin{array}{l}\text { Increased neuroprotection from asphyxial } \\
\text { cardiac arrest }\end{array}$ \\
\hline Kanoria et al. [257] & Rabbit & Liver & $\begin{array}{l}\text { Reduced liver I/R injury and improved liver } \\
\text { function }\end{array}$ \\
\hline Lai et al. [258] & Rat & Liver & $\begin{array}{l}\text { RIPC stimulated heme oxygenase- } 1 \text { expression } \\
\text { in liver tissue and associated with liver } \\
\text { protection from I/R injury }\end{array}$ \\
\hline Cheung et al. [259] & Human & Heart & $\begin{array}{l}\text { Postoperative improvement in lung function } \\
\text { and reduction in plasma troponin-I level }\end{array}$ \\
\hline Mudaliar et al. [260] & Rat & Heart & $\begin{array}{l}\downarrow \text { Infarct size through JAK-STAT pathway } \\
\text { upregulation }\end{array}$ \\
\hline
\end{tabular}

Note: CAO: coronary artery occlusion, OCABG: off-pump coronary artery bypass, LV: left ventricular

organ abolishes RIPC protection [34, 35]. In contrast Konstantinov and colleagues show that denervation of the recipient donor heart does not eliminate the RIPCinduced MI size reduction effect [24]. However, the 
exact role of the afferent and efferent component of the neural pathway is unclear. The involvement of the neural pathway in RIPC-mediated cardioprotection was explored by Gho et al. who demonstrated that transient occlusion of the anterior mesenteric artery can mediate cardioprotection, which can be abrogated by ganglionic blockers [22]. This finding was supported with the proposition that RIPC propels the production of autacoids such as adenosine, bradykinin, CGRP in the remote preconditioned organ, which stimulates afferent nerves and relays the neural signal to the myocardium via the efferent nerve fibers. Furthermore, Ding et al. explored the role of renal nerve-mediated cardioprotection [36]. They confirmed that renal nerve resection abolished renal preconditioning-induced cardioprotection. Liem et al. provided confirmatory evidence implicating adenosine in a neural pathway of cardioprotection [37]. They reported that adenosine released by the mesenteric artery during preconditioning reduced myocardial infarct size from $68 \%$ to $48 \%$, a protective effect that was reversed by the ganglionic blocker hexamethonium. In addition, intramesenteric artery infusion of adenosine mimicked similar cardioprotection as mesenteric arteryinduced preconditioning, which could be abolished by hexamethonium. From these findings, the investigators concluded that locally released adenosine during mesenteric artery preconditioning stimulates afferent nerves in the mesenteric bed which helps activate myocardial adenosine receptors. Dong et al. demonstrated that dissecting the femoral nerve prior RIPC does not protect the myocardium against $\mathrm{I} / \mathrm{R}$ injury and suggested that an intact neural pathway was required for the sensory afferent neural signaling from the preconditioned limb [38]. A study carried out by Jones and colleagues showed that instead of IPC, abdominal slit in mice activates the cardiac sensory and sympathetic nerves. This procedure elicits cardioprotection via bradykinin (a known hormone and neurotransmitter) release in the heart by the sympathetic nerves and bradykinin dependent activation of PKC- $\varepsilon$ [21].

\section{Systemic pathway}

Remote ischemic conditioning has been shown to provoke a systemic response by modulating inflammatory cells either post-transcriptionally or through transcriptional regulation [39]. In contrast to the humoral pathway, the systemic pathway involves the inflammatory cells and provokes an inflammatory response to confer the RIPC signal. Kharbanda et al. previously showed that RIPC reduced expression of neutrophil CD11b and platelet-neutrophil complexes in humans [40]. In 2004, Konstantinov et al. used microarray analysis of blood samples from healthy human volunteers subjected to forearm preconditioning to reveal that preconditioning suppressed genes regulating cytokine production, leukocyte chemotaxis, adhesion and migration, exocytosis, innate immunity, signaling pathways, and apoptosis, while up-regulating anti-inflammatory genes such as HSP-70 and calpastatin [41]. Later, the same

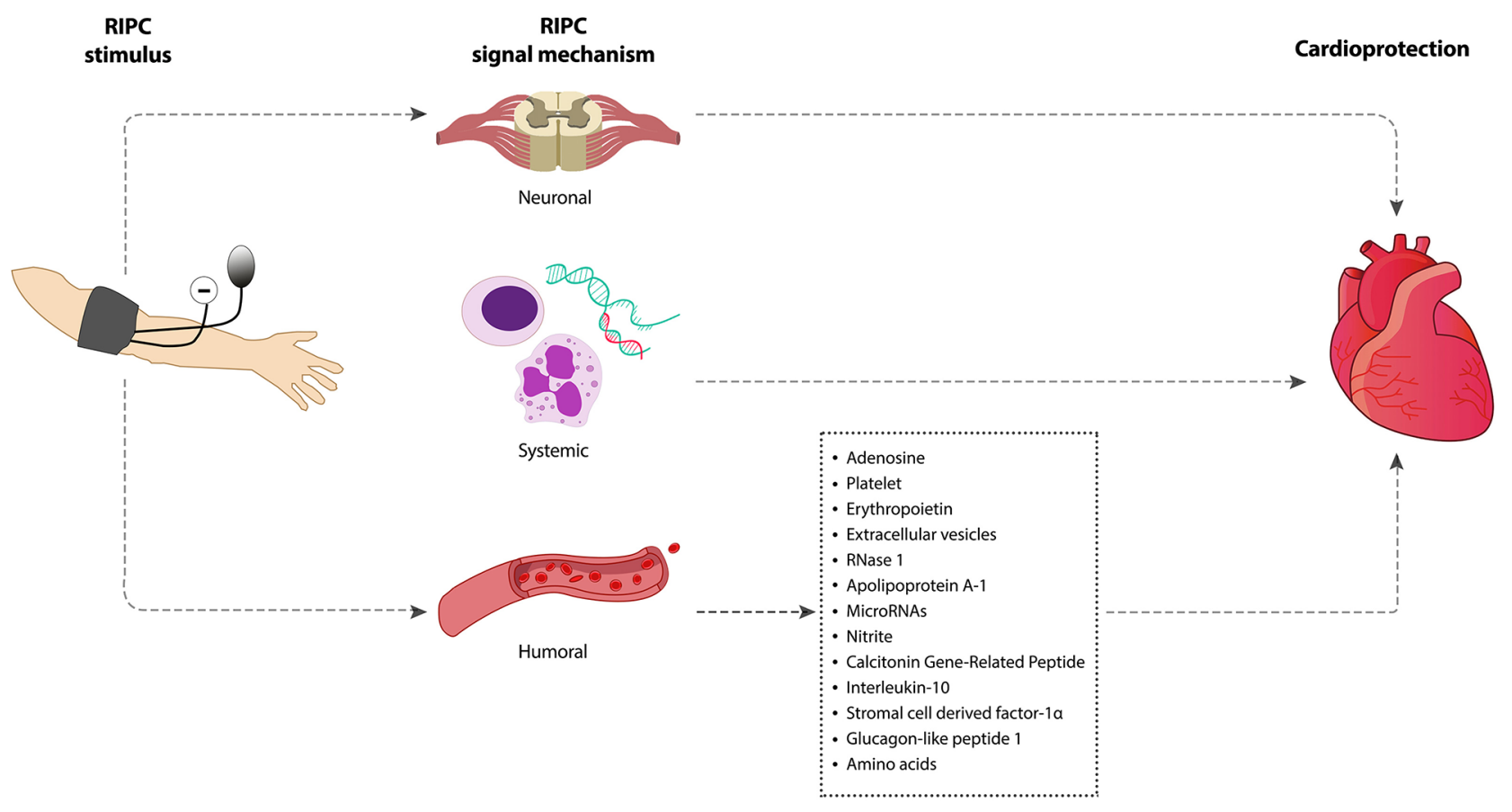

Figure 1: Signaling mechanisms underpinning RIPC-induced cardioprotection. Intermittent limb ischemia and reperfusion confers cardioprotection through neuronal, systemic and humoral mechanism. 
Table 3: Key animal studies on mechanisms of RIPC-induced organ protection

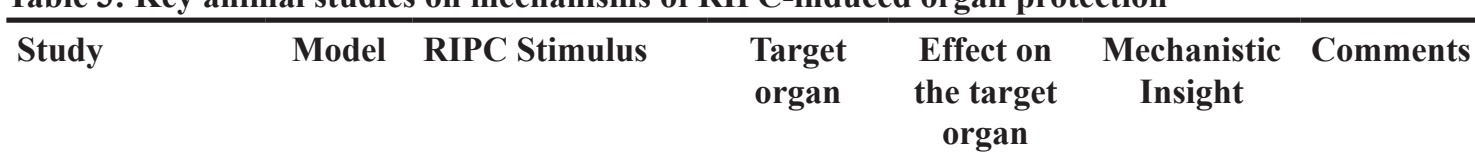

\begin{tabular}{|c|c|c|c|c|c|c|}
\hline Gho et al. [22] & Rats & $\begin{array}{l}\text { i) } 15 \text { min CAO } 10 \\
\text { min reperfusion } \\
\text { ii) } 15 \text { min MAO } 10 \\
\text { min reperfusion } \\
\text { iii) } 15 \text { min renal } \\
\text { artery occlusion } 10 \\
\text { min reperfusion }\end{array}$ & Heart & $\downarrow$ Infarct size & $\begin{array}{c}\text { Neural } \\
\text { pathway }\end{array}$ & $\begin{array}{l}\text { Ganglion blocker } \\
\text { abolished RIPC effect } \\
\text { while maintaining direct } \\
\text { preconditioning effect }\end{array}$ \\
\hline $\begin{array}{l}\text { Schoem-aker } \\
\text { and Heijningen } \\
\text { [92] }\end{array}$ & Rats & $\begin{array}{l}15 \text { min intestinal } \\
\text { ischemia } 10 \mathrm{~min} \\
\text { reperfusion }\end{array}$ & Heart & $\downarrow$ Infarct size & $\begin{array}{c}\text { Neural } \\
\text { pathway }\end{array}$ & $\begin{array}{l}\text { Bradykinin, Hexamethonium } \\
\text { may be activating the neural } \\
\text { pathway }\end{array}$ \\
\hline Liem et al. [37] & Rats & $\begin{array}{l}15 \text { min intestinal } \\
\text { ischemia } 10 \mathrm{~min} \\
\text { reperfusion }\end{array}$ & Heart & $\downarrow$ Infarct size & $\begin{array}{c}\text { Neural } \\
\text { pathway }\end{array}$ & $\begin{array}{l}\text { RIPC mediated adenosine } \\
\text { upregulation conferred } \\
\text { protection against I/R and } \\
\text { adenosine receptor blocking } \\
\text { abolished RIPC protection }\end{array}$ \\
\hline Dong et al. [38] & Rats & $\begin{array}{l}10 \mathrm{~min} \text { hind } \operatorname{limb} \\
\text { ischemia } 10 \mathrm{~min} \\
\text { reperfusion }\end{array}$ & Heart & $\downarrow$ Infarct size & $\begin{array}{c}\text { Neural } \\
\text { pathway }\end{array}$ & $\begin{array}{l}\text { Dissecting femoral nerve of } \\
\text { the hind limb prior to RIPC } \\
\text { abolished the RIPC effect on } \\
\text { the target organ }\end{array}$ \\
\hline Tang et al. [100] & Rabbits & $\begin{array}{l}10 \text { min intestinal } \\
\text { ischemia } 15 \mathrm{mins} \\
\text { reperfusion }\end{array}$ & Heart & $\downarrow$ Infarct size & $\begin{array}{c}\text { Neural } \\
\text { Pathway }\end{array}$ & $\begin{array}{l}\text { RIPC mediated protective } \\
\text { effect is associated with } \\
\text { capsaicin-sensitive sensory } \\
\text { nerves activation }\end{array}$ \\
\hline $\begin{array}{l}\text { Brzozowski et } \\
\text { al. [236] }\end{array}$ & Rats & $\begin{array}{l}\text { i) } 2 \text { cycles of } 5 \\
\text { min left anterior } \\
\text { descending artery } \\
\text { occlusion and } 5 \\
\text { min reperfusion } \\
\text { ii) } 2 \text { cycles of } 5 \\
\text { min occlusion of } \\
\text { common hepatic } \\
\text { artery and portal } \\
\text { vein followed by } \\
10 \text { min reperfusion }\end{array}$ & Gut & $\begin{array}{l}\downarrow \text { Gastric } \\
\text { mucosal } \\
\text { lesion }\end{array}$ & $\begin{array}{c}\text { Neural } \\
\text { pathway }\end{array}$ & $\begin{array}{l}\text { Conferred gastroprotection } \\
\text { via vagal and sensory nerve } \\
\text { mediated vasodilatory } \\
\text { mediators }\end{array}$ \\
\hline $\begin{array}{l}\text { Weinbrenner et } \\
\text { al. [23] }\end{array}$ & Rabbits & $\begin{array}{l}15 \text { min infra-renal } \\
\text { aortic ischemia } 10 \\
\text { min reperfusion }\end{array}$ & Heart & $\downarrow$ Infarct size & $\begin{array}{l}\text { Humoral } \\
\text { Pathway }\end{array}$ & $\begin{array}{l}\text { Neural ganglion blocker } \\
\text { could not abolish RIPC } \\
\text { effect }\end{array}$ \\
\hline Patel et al. [233] & Rats & $\begin{array}{l}15 \text { min } \mathrm{MAO} \\
\text { followed by } 10 \mathrm{~min} \\
\text { reperfusion }\end{array}$ & Heart & $\downarrow$ Infarct size & $\begin{array}{l}\text { Neural } \\
\text { pathway }\end{array}$ & $\begin{array}{l}\text { Preconditioning-induced } \\
\text { opioid release and opioid } \\
\text { receptor activation protected } \\
\text { the myocardium from } \\
\text { ischemic injury. Opioid } \\
\text { receptor antagonist abolished } \\
\text { the protection }\end{array}$ \\
\hline
\end{tabular}

(Continued) 


\begin{tabular}{|c|c|c|c|c|c|c|}
\hline Study & Model & RIPC Stimulus & $\begin{array}{l}\text { Target } \\
\text { organ }\end{array}$ & $\begin{array}{l}\text { Effect on } \\
\text { the target } \\
\text { organ }\end{array}$ & $\begin{array}{l}\text { Mechanistic } \\
\text { Insight }\end{array}$ & Comments \\
\hline $\begin{array}{l}\text { Konstantinov et } \\
\text { al. [41] }\end{array}$ & Human & $\begin{array}{l}3 \text { cycles of } 5 \\
\text { min forearm } \\
\text { ischemia and } 5 \mathrm{~min} \\
\text { reperfusion }\end{array}$ & Leukocytes & $\begin{array}{l}\text { Decreased } \\
\text { CD11B } \\
\text { expression } \\
\text { on } \\
\text { leukocytes }\end{array}$ & $\begin{array}{l}\text { Systemic } \\
\text { pathway }\end{array}$ & $\begin{array}{l}\text { Suppressed pro- } \\
\text { inflammatory and pro- } \\
\text { apoptotic gene transcription }\end{array}$ \\
\hline $\begin{array}{l}\text { Wolfrum et al. } \\
{[105]}\end{array}$ & Rats & $\begin{array}{l}15 \mathrm{~min} \text { MAO } \\
15 \mathrm{~min} \text { reperfusion }\end{array}$ & Heart & $\downarrow$ Infarct size & $\begin{array}{l}\text { Humoral } \\
\& \text { Neural } \\
\text { pathway }\end{array}$ & $\begin{array}{l}\text { RIPC increased plasma } \\
\text { CGRP level and CGRP } \\
\text { activated PKC } \varepsilon \text { via neural } \\
\text { pathway }\end{array}$ \\
\hline $\begin{array}{l}\text { Zhang et al. } \\
{[255]}\end{array}$ & Rats & $\begin{array}{l}3 \text { cycles of } 5 \\
\text { min femoral } \\
\text { artery occlusion } \\
\text { followed by } 5 \mathrm{~min} \\
\text { reperfusion }\end{array}$ & Heart & $\downarrow$ Infarct size & $\begin{array}{l}\text { Neural } \\
\text { pathway }\end{array}$ & $\begin{array}{l}\text { Activation of kappa- } \\
\text { opioid receptors provided } \\
\text { cardioprotection induced by } \\
\text { RIPC and mPTP inhibition is } \\
\text { downstream of kappa-opioid } \\
\text { receptor activation }\end{array}$ \\
\hline $\begin{array}{l}\text { Konstantinov et } \\
\text { al. [24] }\end{array}$ & Pigs & $\begin{array}{l}4 \text { cycles of } 5 \\
\text { min lower limb } \\
\text { ischemia } 5 \text { min } \\
\text { reperfusion }\end{array}$ & Heart & $\downarrow$ Infarct size & $\begin{array}{l}\text { Humoral } \\
\text { pathway }\end{array}$ & $\begin{array}{l}\text { K ATP channel dependent } \\
\text { mechanism provided RIPC- } \\
\text { induced cardioprotection and } \\
\text { excluded afferent neurogenic } \\
\text { mechanism }\end{array}$ \\
\hline Jones et al. [21] & Mice & $\begin{array}{l}\text { Abdominal incision } \\
\text { for RIPC of trauma }\end{array}$ & Heart & $\downarrow$ Infarct size & $\begin{array}{l}\text { Neural } \\
\text { pathway }\end{array}$ & $\begin{array}{l}\text { Skin nociception provided } \\
\text { cardioprotection through } \\
\text { neurogenic signaling } \\
\text { involving spinal cords and } \\
\text { activation of cardiac sensory } \\
\text { and sympathetic nerves }\end{array}$ \\
\hline
\end{tabular}

Note: CAO: coronary artery occlusion, MAO: mesenteric artery occlusion.

group provided evidence to show that RIPC upregulated genes associated with growth and metabolism, DNA repair and redox regulation. IPC attenuated P-selectin expression in liver and prevented neutrophil infiltration in lung, stomach, pancreas, small intestine and colon via inhibition of systemic TNF- $\alpha$ production [42]. In another study, Albrecht et al. reported similar findings in human, showing that within the early phase of RIPC, serum cytokines were upregulated [43]. It may be that, cytokines function as both pro- and anti-inflammatory mediators in ischemic conditioning to prepare the target organ to mitigate the tissue damage. This group's findings showed concurrent increase of IL-8, IL-1 $\beta$, TNF- $\alpha$ and concurrent cardioprotection due to increased neutrophil infiltration after right atrial bypass surgery [43].

\section{CIRCULATING MEDIATORS OF ISCHEMIC CONDITIONING}

Remote preconditioned organ may require a 'flush' after brief ischemia in order to transport humoral factors to the target organ generated by the preconditioning stimulus [19]. Number of studies focused on identifying the nature of the circulating mediators in bloodstream, which likely carries the preconditioning signal from the remote organ to the target organ $[29,30,32]$. Though the actual identity remains elusive, below we discuss a number of blood borne mediators known to be involved in mediating the RIPC-induced protection to the heart against I/R injury.

\section{Adenosine}

Adenosine plays an important role in many biochemical processes including energy transfer, signal transduction or as a neuromodulator. Myocardium expresses several adenosine receptors [44]. Activation of adenosine receptors provides a myocardial preconditioning like affect in rabbits [45], dogs [46] and pigs [47]. Adenosine activates toxin sensitive $G$ protein, which can activate ATP sensitive $\mathrm{K}^{+}$channel [48]. Surendra and colleagues previously showed that $\delta$-opioid and $\kappa$-opioid receptors interact with adenosine 
A1 receptors to mediate RIPC-induced cardioprotection [49]. Furthermore, activation of the ATP sensitive $\mathrm{K}^{+}$channel has been demonstrated to be involved in myocardial preconditioning in dogs. Conversely, neither adenosine [50] nor the ATP sensitive $\mathrm{K}^{+}$channel [51] confer a protective effect in myocardial preconditioning in a similarly designed rat model. However, using the adenosine receptor inhibitor, Takaoka and colleagues have shown the contribution of adenosine in RIPC through renal artery $\mathrm{I} / \mathrm{R}$ in a rabbit model and reported reduction of $\mathrm{MI}$ size [52]. AMISTAD-I trial with 'reduced MI size by 50\% [53]. This study was followed by a large-scale AMISTAD II trial which recruited over 2000 patients undergoing PCI or thrombolysis for anterior STEMI but found no effect of adenosine infusion in terms of death or heart failure $[54,55]$. However, patients who received PCI within the first few hours $(<3.17 \mathrm{~h})$ from the onset of the symptoms and received adenosine infusion showed lower mortality and heart failure in post hoc analysis.

\section{Platelet dependent signaling}

Platelet activation by mechanical pressure, ischemia or tissue damage invokes a systemic response as one of the first lines of protective defense. Oberkofler et al. addressed the role of activated platelet derived serotonin in RIPC-mediated liver and kidney protection against I/R [56]. This group showed that RIPC-induced reduction of $\mathrm{I} / \mathrm{R}$ injury is associated with prompt release of serotonin by activated platelets and serotoninmediated activation of the VEGF/IL-10/MMP8 pathway. Reducing platelet numbers by more than $90 \%$ by inducing thrombocytopenia with an anti-CD41 injection abolished the RIPC-mediated protection against liver I/R injury and increased of both ALT/AST levels. RIPC displayed a $40 \%$ reduction in platelet numbers and when platelet activation was blocked with the platelet-activating factor (PAF) receptor antagonist SM-12502, the effect of RIPC was eliminated. This supports the importance of platelet activation for RIPC. This study demonstrated that serotonin plays a crucial role in platelet dependent protection mechanisms. When tryptophan hydroxylase 1 $\left(\mathrm{Tph}^{-/-}\right)$mice lacking platelet serotonin were subjected to RIPC prior to hepatic I/R injury, they did not show any reduction in $\mathrm{I} / \mathrm{R}$ injury. This result however was reversed by injecting $5 \mathrm{HTP}$, a serotonin precursor. Further studies aimed at elucidating the downstream effector of serotonin found that RIPC resulted in significant increase in serum vascular endothelial growth factor (VEGF) levels, which is cardioprotective [57] and can be upregulated by serotonin [58]. Recombinant VEGF-A treatment prior to $\mathrm{I} / \mathrm{R}$ resulted in similar effects of RIPC, whilst anti-VEGF antibody treatment abolished the RIPC effect, supporting the importance of circulating VEGF in RIPC. In addition, RIPC upregulated IL-10 and MMP-8 expression in liver, heart, kidney, lung, and intestine. Similar results have been achieved by treating mice with serotonin. Despite these results, IL-10 $0^{-/}$mice with MMP-8 inhibition showed total amelioration of the RIPC-mediated protection, implicating the involvement of serotonin-VEGF-IL-10/MMP-8 axis in facilitating the systemic organ protection induced by platelet activation.

\section{Erythropoietin}

Erythropoietin (EPO) is a circulatory $30 \mathrm{kDa}$ glycoprotein, a principal regulator of red blood cell production. This 165 -amino acid long protein has 4 glycosylated chains, which renders its biological activity and protects it from oxygen radicals. Previous studies have shown that exogenous administration of EPO as well as increased endogenous serum EPO improves MI pathobiology by reducing the infarction size as well as improving cardiac function in a time dependent manner [59-62]. EPO can prevent apoptotic cell death in isolated cardiomyocytes by activating the JAK2-PI3K-AKT signaling as well as by suppressing glycogen synthase kinase-3 $\beta$, a serine-threonine kinase that induces apoptosis in various cell types including vascular smooth muscle cells, cardiomyocytes, and neurons [63-68]. Previously Oba et al. demonstrated that renal nerve-mediated EPO release is essential for RIPC-induced cardioprotection [69]. In a mouse model with 4 cycles of 5 min hypoxia and reoxygenation there was an increase in serum EPO levels in a time dependent manner, which peaked $1 \mathrm{~h}$ post RIPC and returned to basal levels $24 \mathrm{~h}$ post RIPC. Similar findings were obtained in a human study of RIPC with 3 cycles of $5 \mathrm{~min}$ of upper arm ischemia and $5 \mathrm{~min}$ reperfusion. In both cases, cardioprotective cytokines such as interleukin-6, G-CSF, and leukemia inhibitory factor in serum did not change. RIPC reduced renal blood flow $(\mathrm{RBF})$ in mice with production and secretion of EPO, which is regulated by tissue oxygen supply. Hypoxic tissue results in increased production of EPO and EPO receptors (EPOR). RIPC activated the HIF-1a-EPO pathway and reduced MI size after $2 \mathrm{~h}$ of permanent occlusion of the left coronary artery. In addition, injecting the anti-EPO neutralizing antibody $24 \mathrm{~h}$ prior to RIPC abolished the RIPC-induced attenuation of infarct size. However, there is controversy regarding the role of renal nerves in EPO production. Oba's group also found that renal denervation abolished RIPC-mediated serum EPO elevation and hence the reduction of MI size. This study elegantly demonstrated that RIPC-mediated EPO secretion by the kidney is renal nerve activity-dependent and can limit the MI pathology. RIPC failed to confer cardioprotection in rats with renal failure, which may be attributed to the lack of EPO release during renal failure [70]. Further insight into signals transduced from the preconditioned limb to the kidney to stimulate the process of EPO production is still needed. 


\section{Extracellular vesicles}

Extracellular vesicles (EV) is a collective term for vesicles which are 30-100 nm (exosomes) and 100-1000 $\mathrm{nm}$ (microvesicles/micropartciles) in diameter. EV's have many functions and abilities, one of which is to act as transport for proteins, miRNAs and signaling between cells [71]. Giricz et al. demonstrated in the Langerdorff rat heart model that preconditioning increases the number of extracellular vesicles (EV) released into the coronary perfusate [72]. They found that perfusate collected from preconditioned heart reduced MI size significantly, whereas perfusate depleted of EV showed no signs of reducing the infarction size. A subsequent study by Vincencio et al. determined that endogenous plasma exosomes from rats and human subjected to remote ischemic preconditioning activated pro-survival signally in cardiomyocytes through toll-like receptor 4, leading to activation of ERK1/2, MAPK signaling pathways leading to phosphorylation of the cardioprotective heat shock protein 27 (HSP27) [73]. Similarly, Davidson et al. demonstrated that pre-incubation of purified HUVEC exosomes reduced the cell death of rat cardiomyocytes after stimulation of ischemic reperfusion injury [74]. In this case, exosomes activated the ERK1/2, MAPK signaling pathway which contributes to cardioprotection. Furthermore, Mighua et al. found increased levels of miR24 in plasma exosomes of rats subjected to RIPC [75]. They found that miR-24 production after RIPC was able to reduced cardiomyocyte apoptosis, reduce infarct size and improve heart function. Whilst these studies are promising there is still more research to be conducted to understand the signaling and effector mechanism of the extracellular vesicles.

\section{RNase1}

Extracellular RNA (eRNA) functions as an early signal for tissue stress or damage and provides a signal to release cytokines like TNF- $\alpha$ and mediate leukocyte trafficking and consequently inflammatory processes [76]. RNase1 has been shown to prevent the crosstalk between eRNA and TNF- $\alpha$ in mouse cardiac I/R injury model and isolated langendorf-perfused rat heart model [77]. RNase1 is ubiquitously expressed and the presence of highly specific RNase inhibitors limits its cytotoxicity in the cells. Apart from the gastrointestinal tract, which is the primary site for RNase1 production, vascular endothelial cells also produce RNase1 [78] primarily during stress [79]. Previously Cabrera-Fuentese and colleagues demonstrated that, RIPC prior to cardiac surgery decreased pathological eRNA and TNF- $\alpha$ expression in patients which was otherwise more than 20-fold and 7-fold higher without RIPC, respectively [80]. Furthermore, RIPC increased the plasma RNase1 activity by more than 5 -fold when compared with the control. It has been subsequently proposed that RIPC dependent endothelial release of RNase1 degrades eRNA and prevents its interaction with TNF- $\alpha$ and other proteins to limit the pathological features of I/R. However further studies that alter RNase 1 activity in the RIPC model are required to further understand the molecular process of protection mediated by RNase 1 .

\section{Apolipoprotein A-I}

Apolipoprotein A-I (ApoA-I) is the major component of high-density lipoprotein in plasma. Hilbert et al. previously demonstrated the potential for ApoA-I as a circulatory mediator of RIPC-induced cardioprotection in Wistar rats [81]. They found that, $10 \mathrm{~min}$ of limb reperfusion after $10 \mathrm{~min}$ of limb ischemia increased plasma ApoA-I by 30\% compared to untreated control group, whilst $5 \mathrm{~min}$ of limb reperfusion after $10 \mathrm{~min}$ of limb ischemia did not change the plasma ApoA-I level compared to the untreated rats. When Apo-AI was injected as an intravenous bolus $(10 \mathrm{mg} / \mathrm{kg}) 10 \mathrm{~min}$ prior to ischemia for $40 \mathrm{~min}$ and a reduction of almost $15 \%$ in MI size was reported after $2 \mathrm{~h}$ of reperfusion. A rat plasma proteomic study by Lang et al. did not report differential expression of ApoA-I in blood plasma after RIPC [32]. However, there were key differences between the two studies; Hibert et al. used renal artery occlusion whereas Lang et al. used hind limb occlusion to induce RIPC effect. In addition, the reperfusion time after ischemia was also different between the two studies. The beneficial effect of ApoA-I may be attributed to its ability to scavenge the TNF- $\alpha$ released by the myocardial tissue. Also, intravenous administration of ApoA-I prior to renal pedicle ischemia and prior to myocardial reperfusion limits the I/R-mediated injury. This includes reduced cytokine production by the injured tissue and suppressed endothelial ICAM-1 expression along neutrophil adherence and migration. Though the molecular mechanisms behind the increased expression of ApoA-I in the blood remains unclear, the quick response to RIPC by increasing the plasma concentration of ApoA-I led to a theory that suggests that RIPC does not increase the level of new ApoA-I synthesis but mobilizes the existing ApoA-I. Further studies are required to delineate the proposed theory.

\section{MicroRNAs}

MicroRNAs (miRNA) are a class of endogenous small non-coding RNAs that circulate in a stable form in blood and regulate posttranslational gene expression. Previously, $\mathrm{Li}$ and colleagues reported that circulating microRNA-144 (miR-144) plays an important role in MI sparing effect of RIPC in mice [82]. Previously Zhang et al. observed that overexpression of miR-144 and miR151 augmented cytoprotection in response to simulated I/R injury [83]. Also, local IPC-mediated myocardial functional recovery was lost in antagomiR-51 treated 
hearts in a murine model but failed to mimic similar result in miR-144 treated hearts suggesting that miR-144 may not be an important regulator of cytoprotection in IPC. $\mathrm{Li}$ and colleagues followed up by exploring the role of miR-144 in RIPC. They demonstrated that RIPC increased plasma miR-144 in both mice and human. In addition, RIPC also showed an increase in myocardial expression of miR-144 in mice, whereas I/R injury decreased myocardial expression of miR-144. Intravenous administration of miR-144 conferred both early (I/R injury immediately after miR-144 administration) and delayed (I/R injury after 3 consecutive days of miR-144 administration) cardioprotection whereas antisense oligonucleotide targeting miR-144 (antagomiR-144) abolished the RIPC effect on the heart. Microvesicles and exosomes are the major carrier of circulating miRNA, however analysis of the active constituent of the micro-particles (50-400 $\mathrm{nm}$ ) showed no significant increase in micro-particle numbers and miR-144 which contradicts with the finding of Giricz et al. [72]. This may be due to differences in microparticle isolation, purification, microparticle size and different protocols of RIPC. Conversely, the exosome pellet showed almost 4-fold increase in miR-144 precursor and an increase in miR-144 in exosome-poor serum [72]. This group then demonstrated that miR-144 binds with Argonaute-2, a known extracellular miRNA carrier. Although the source of miR-144 and the exact mechanism of action of miR-144 in the heart are not clear, the phosphorylation of protective kinases such as Akt, GSK$3 \beta$, p42/44 MAPK increased while inducing autophagy signaling as early as $1 \mathrm{~h}$ after administration of miR144. These findings suggest a vital role of miR-144 as a circulating mediator of RIPC and plasma miR-144 may be a potential biomarker for the successful application of preconditioning, aiding the study of efficacy of RIPC and abrogation of RIPC in clinical trials.

Mingua and colleagues studied nine microRNAs including miR-150, miR-21, miR-195, miR-132, miR140, miR-144, miR-24, miR-214, miR-34a and found that RIPC significantly upregulated only miR-24 in the rat plasma exosomes [84]. Moreover, miR-24 down-regulated pro-apoptotic Bim protein expression and conferred cardioprotection. However, this group did not observe any alteration in miR-144 level in the exosomes after RIPC. Though the RIPC stimulus protocol in this study was the same as Li and colleagues [82], the disparity in miR-144 level after RIPC may be attributable to species difference.

\section{Nitrite}

Ischemia and shear stress depolarizes cell membrane and inhibits the function of $\mathrm{K}^{+}$channels. Inhibition of $\mathrm{K}^{+}$channels lead to activation of $\mathrm{Ca}^{2+}$ channels and increased $\mathrm{Ca}^{2+}$ influx into endothelial cells and activates $\mathrm{Ca}^{2+}$ dependent endothelial nitric oxide synthase (eNOS). Pharmacological and genetic techniques revealed that,
eNOS in the endothelial cells are the source of nitrite production during reactive hyperemia, which is then readily transported to the target organ especially to the myocardium. RIPC does not phosphorylate myocardial Akt and Erk proteins, which supports the notion that nitrite in the heart is remotely produced [85]. Hypoxia and ischemia inhibits oxidative phosphorylation, impairs ATP production and activates xanthine oxidase [86]. Davidson and colleagues reported that glyceryl trinitrite (GTN) patch $(0.026 \mathrm{mg} / \mathrm{h})$ reduced MI size in mouse model and improved blood pressure [87]. The degree of protection achieved by GTN patch was similar to that achieved by 3 cycles of 5 min RIPC. Similarly, a recent study by Hauerslev et al., suggests that long term application of GTN or RIPC is protective against ischemia-reperfusion injury, however a combined treatment eliminates this protective effect, suggesting a clinically relevant interaction [88]. Previous findings in humans, reported that forearm intermittent I/R modulates plasma NO / nitrite levels [89, 90]. Nitrite, the oxidation product of $\mathrm{NO}^{\circ}$ is a stable reservoir of $\mathrm{NO}^{\circ}$ and has a halflife of approximately $35 \mathrm{~min}$ [91]. Rassaf and colleagues demonstrated that, reactive hyperemia is essential to significantly improve the eNOS derived plasma nitrite levels. In addition, $\mathrm{eNOS}^{-/-}$mice totally abrogated the MI sparing effect as well as diminishing the RIPC linked increase of plasma and myocardial nitrite levels. They also matched RIPC-mediated increased level of circulating nitrite with exogenous supplementation of intravenous nitrite and reported similar level of cardioprotection as RIPC [85]. These findings shed further light on why the effect of RIPC is not as pronounced in humans with pathological conditions such as atherosclerosis and coronary artery disease, given that endothelial function in these patients is partly impaired and impacts circulating nitrite levels.

\section{Calcitonin Gene-Related Peptide (CGRP)}

Recent studies have characterized the involvement of capsaicin sensitive sensory neurons in RIPC [92, 93]. Sensory neurons are widely spread throughout the mammalian cardiovascular system and contain cardiostimulatory neuropeptides. Among the neuropeptides, calcitonin gene-related peptide (CGRP), substance $\mathrm{P}$ and other neurokines play an intricate role in modulating cardiac function through local cardiac reflexes [94-96]. CGRP release is regulated by multiple factors such as brief ischemia, hyperthermia or autocoids [97-99]. Plasma levels of CGRP are increased by brief anterior mesenteric artery occlusion [100]. Furthermore, CGRP is involved in facilitating preconditioning-induced protection [101-103]. Similarly, it confers early and delayed cardioprotection against reperfusion injury in vivo [100] and in isolated rat heart [101]. CGRP facilitated early preconditioning is thought to involve only the release of CGRP whilst 
delayed preconditioning involves increased a-CGRP but not $\beta$-CGRP expression via $\mathrm{NO}$ and/or $\mathrm{CO}$ pathways [104]. Wolfrum and colleagues explored the role of CGRP in $\mathrm{MI}$ in vivo and delineated its role in the transduction mechanism of RIPC to the heart [105]. This group remotely preconditioned rat heart by occluding the mesentery artery for $15 \mathrm{~min}$ followed by $15 \mathrm{~min}$ reperfusion. RIPC by mesentery artery occlusion (MAO) in rats reduced MI size by around $40 \%$ and increased plasma CGRP levels by almost $40 \%$, which was comparable to the plasma level of CGRP after pharmacological preconditioning by low dose of CGRP. Even though CGRP has a vasodilatory effect, a low dose of CGRP is protective against MI and limits infarction size without affecting hemodynamics. In addition, ganglion blocker hexamethonium did not prevent CGRP release after mesenteric preconditioning, but it abolished CGRP-mediated activation of myocardial PKC $\varepsilon$ and proved that neural response to RIPC is due to the systemic release of CGRP [105]. Peng and colleagues used CGRP receptor antagonist, $\mathrm{CGRP}_{8-37}$, to show that ischemic preconditioning-mediated cardioprotection involves CGRP whilst pre-treatment with CGRP receptor antagonist $\mathrm{CGRP}_{8-37}$ reversed the $\mathrm{MI}$ size limiting effect and $\mathrm{PKC} \varepsilon$ translocation [106]. These findings suggest that CGRP is a humoral mediator of RIPC which further targets downstream neural pathways to confer cardiac protection.

\section{Interleukin-10}

RIPC has been shown to modulate gene expression for proteins involved in inflammatory responses such as leukocyte chemotaxis, adhesion to endothelial cells, migration, exocytosis, cytokine synthesis, innate immune response and apoptosis in circulating human neutrophils [41, 107]. Late RIPC inhibits inflammatory responses in reperfused tissues. Interleukin-10 (IL-10) is an antiinflammatory cytokine that decreases production of chemokines and cytokines [108] and can activate prosurvival pathways [109, 110]. IL-10 has two receptor subunits IL-10R1 and IL-10R2. IL-10R1 is expressed by all IL-10 responsive cells whereas IL-10R2 is ubiquitously expressed. IL-10R1 receptors are expressed on cardiomyocytes [111]. Late RIPC reduced infarct size and increased left ventricular developed pressure (LVDP), which was reversed by treating the heart with IL-10 receptor antibodies [111]. RIPC did not have cardioprotective effects on IL-10 knockout mice and on wild type mice treated with IL-10 receptor antibodies blocking the binding of IL-10 to IL-10R1. However pretreatment of IL-10 knockout mice with recombinant IL10 significantly decreased infarct size [111]. Furthermore, the size of IL-10 (18 kDa) is consistent with notion that humoral mediators are likely to be $<30 \mathrm{kDa}$ [108]. Increased plasma IL-10 levels can quickly accumulate in tissue due to IL-1 receptor expression and high affinity for
IL-10 on cardiomyocytes. Conversely, IL-10 can increase its own expression in tissue [112, 113]. Cai and colleagues showed that late RIPC increased plasma and cardiac IL-10 level at $24 \mathrm{~h}$ and activated Akt-eNOS signaling pathway through IL-10 receptors in myocardium while upregulating IL-10 expression in preconditioned skeletal muscle [111]. Whether increased plasma and cardiac IL-10 is released from the preconditioned skeletal muscle remains unclear.

\section{Interleukin-1 Alpha}

Interleukin-1 Alpha (IL-1 $\alpha$ ) is an inflammatory mediator and released by macrophages, monocytes, endothelial and epithelial cells $[114,115]$. Lugrin and colleagues demonstrated in mice MI model that, cardiomyocytes also release IL- $1 \alpha$ into the systemic circulation without elevating the myocardial IL-1 $\alpha$ level [116]. IL-1 $\alpha$ blocking and IL- $1 \alpha$ receptor antagonist has been reported to reduce myocardial I/R injury [117-119]. Gedik and colleagues reported that, RIPC on the upper arm of human significantly increased circulating IL- $1 \alpha$ compared to placebo and remained increased until further cardioplegic arrest [120]. As both CABG surgery and RIPC have a systemic response [121-123], the study by Gedik and colleagues [120] raised the question whether the observed increase in IL- $1 \alpha$ is due to I/R injury or RIPC. It has been suggested that, IL- $1 \alpha$ may indirectly activate cardioprotective signaling pathways by IL-6 induction [124]. Preconditioning and pretreatment with exogenous IL- $1 \alpha$ in isolated perfused rat heart improved myocardial function and reduced MI size suggesting the cardioprotective effect of circulating IL-1 $\alpha$ [125-127].

\section{Stromal cell derived factor-1 $\alpha$}

Stromal cell derived factor- $1 \alpha(\mathrm{SDF}-1 \alpha)$ is a $10 \mathrm{kDa} \mathrm{CXC}$ chemokine involved in recruiting bone marrow derived stem cells at the site of myocardial injury [128]. SDF-1 $\alpha$ can bind to its receptor CXCR4 and protect the isolated heart from acute injury [129]. SDF$1 \alpha$ can also protect the heart from acute injury without engaging the stem cells, either through direct intracardiac administration prior to ischemia in vivo or after perfusion prior to ischemia in isolated hearts ex vivo. SDF-1 $\alpha$ levels increase in response to hypoxia [130]. RIPC has been reported to increase plasma SDF- $1 \alpha$ levels by $50 \%$ in rats and SDF- $1 \alpha$ treatment confers cardioprotection in isolated papillary muscles. This protective effect was abolished by AMD3100, a highly specific inhibitor of CXCR4. In addition, AMD3100 prevented the induction of RIPCinduced cardioprotection in isolated perfused hearts suggesting the involvement of SDF-1 $\alpha$ in RIPC [131]. However, proteomic analysis of human plasma samples confirmed that SDF-1 $\alpha$ was not upregulated after RIPC stimulus [132]. SDF- $1 \alpha$ has a plasma half-life of about 25 min [133]. However, remote postconditioning increased 
SDF- $1 \alpha$ by $1 \mathrm{~h}$, returning to basal level by $3 \mathrm{~h}$ in female Sprague-Dawley rats [134]. Conversely, similar procedure was reported to increase SDF- $1 \alpha$ by $1 \mathrm{~h}$ and $3 \mathrm{~h}$ in mice [135]. It is possible that preconditioning-mediated SDF- $1 \alpha$ regulation and expression are species and time specific. The SDF-1 $\alpha$-/CXCR4 axis is involved in the activation of JAK-STAT, PI3K, and MAPK pathways which are well known mediators of RIPC-induced cardioprotection $[129,136,137]$. Nonetheless, it is not clear whether the endogenous increase in SDF-1 $\alpha$ is sufficient to stimulate RIPC effect in vivo. Further experiments are essential to explain whether SDF-1 $\alpha$ is an RIPC mimetic or can only be used as a biomarker for RIPC optimization.

\section{Glucagon-like peptide 1}

Glucagon-like peptide 1 (GLP-1) is a human incretin hormone, released by the intestine in response to food ingestion $[138,139]$. GLP-1 release in regulated by vagal efferent activity [140, 141]. GLP-1 activity is mediated by GLP-1 receptor (GLP-1R) dependent or independent manner [142, 143]. Several studies have reported the cardioprotective effect of GLP-1 in animal model [142, 144-146]. GLP-1 therapy in clinical settings has also proven to be successful in limiting the reperfusion injury $[147,148]$. The efficiency of GLP$1 \mathrm{R}$ agonists in mediating cardioprotection has also been demonstrated in human [149]. However, the role of GLP-1R in the activation of cardioprotective signaling pathways remains controversial. Basalay and colleagues demonstrated that RIPC conferred cardioprotection by GLP-1R activation and involves M3 muscarinic receptor dependent mechanism [150]. RIPC increased plasma GLP-1 level [150] however, whether this increase in plasma GLP-1 is physiological relevant warrants further discussion. GLP-1 has a low half-life (couple of minutes) and majority of the intestine-produced GLP-1 is rapidly degraded $[151,152]$. However, GLP-1 has a longer lasting beneficial effect even when the circulating level drops to normal level [151]. Previously, Pyke and colleagues suggested that ventricular cardiomyocytes do not express GLP-1R [153]. Nonetheless, GLP-1 and GLP-1R agonists have been reported to have actions in cells and tissues that do not express GLP-1R [154, 155]. In addition, numerous studies have described the direct action of GLP-1R agonists on the myocardium [155]. It is possible GLP-1 mediates RISK pathway activation in the cardiomyocytes via GLP-1 binding to remote GLP-1R on endothelial or smooth muscles cells triggering a paracrine response [139], releasing cardioprotective factors that act on the cardiomyocytes. There is controversy whether the protective effect of GLP-1 therapy can be replicated with RIPC. GLP-1 protects against ischemic left ventricular dysfunction and myocardial stunning following coronary balloon occlusion during elective PCI $[156,157]$, however RIPC does not demonstrate similar effect [158].

\section{Amino acids}

Multiple studies have implicated amino acids as the circulating mediator of RIPC. Alpha-ketoglutaratedependent dioxygenase Egln 1 is ubiquitously expressed and is the primary regulator of HIF-1 $\alpha$ [159]. Egln 1 acts as an oxygen sensor and ischemia inactivates Egln1 [159]. Olenchock and colleagues have demonstrated that Egln1 inhibition in skeletal muscle conferred cardioprotection from I/R injury [160]. This group reported that acute inactivation of Egln1 activity leads to rapid induction of alpha ketoglutarate and systemic level of alpha ketoglutarate increases with declined activity of Egln1. Alpha ketoglutarate is metabolized to kynurenic acid by the liver [160]. Frezza and colleagues demonstrated that, kynurenic acid precursor, kynurenine is upregulated in hypoxic cells [161]. Chao and colleagues reported that, hind limb and forearm preconditioning increase circulating kynurenic acid in rats and human respectively [162]. Exogenous kynurenic acid limits the MI size [160]. However, kynurenic acid level has been found to be high after cardiac arrest in both animal model and in humans [163], underscoring a potential role of kynurenic acid metabolism in RIPC setting.

Glycine, the smallest of the amino acids, protects from I/R-induced necrotic and apoptotic cell death in different target organs and cell types including kidney [164, 165], lung [166], cardiomyocytes [167] and hepatocytes [168]. Glycine has been demonstrated to delay I/R-associated sarcolemma rupture in hepatocytes [169]. Furthermore, glycine prevented mPTP opening in rat isolated mitochondria after I/R [167]. Moreover, glycine prevented myocardial necrosis after prolonged hypoxia or hypoxia-reoxygenation in isolated rat heart $[167,170]$. It has been demonstrated that, RIPC increased circulating glycine level in the blood plasma of a pig model and glycine receptor antagonist pretreatment abolished the protective effect of RIPC plasma dialysate in isolated mice heart, whereas glycine pretreatment reduced MI size [171]. Chao and colleagues reported that, RIPC increased glycine in rat and human plasma, and intraperitoneal delivery of glycine prior to myocardial ischemia reduced MI size in rat [162]. It is possible that glycine receptor activation is involved in RIPC-mediated cardioprotection. However, lower concentrations of glycine failed to confer cardioprotection suggesting that glycine may be essential but not the only mediator of RIPC.

\section{CLINICAL TRIALS}

Multiple studies are currently on-going to assess the efficacy of RIPC in protecting the heart on multiple clinical outcomes. $\mathrm{Su}$ and colleagues have completed a trial on 86 participants to assess the effect of RIPC in patients undergoing $\mathrm{CABG}$, with a primary aim of measuring serum troponin $\mathrm{T}$ level over $72 \mathrm{~h}$ post $\mathrm{CABG}$ 
(NCT03010839) and yet to report the findings. Wang and colleagues have completed a randomised trial with 66 participants to verify the myocardial protective effect of RIPC in patients undergoing off-pump coronary artery and exclusion criteria includes LVEF $<35$, AMI and multiple organ dysfunction (NCT03340181) but yet to report. The primary endpoint of this study is the ICU staying time of the patients after surgery. Similarly, Thielmann and colleagues are recruiting an estimated 800 participants for a phase 2 and phase 3 Germany-based randomised trial to study the effect of RIPC in patients undergoing on-pump CABG with non-propofol anaesthesia and crystalloid cardioplegic arrest with the primary outcome of assessing perioperative extent of myocardial injury by measuring serum troponin I level over $72 \mathrm{~h}$ post CABG surgery (NCT01406678). In addition, Voisine and colleagues are recruiting 140 participants for a randomised trial with a primary objective to verify if RIPC prior to aortic valve replacement surgery can confer cardioprotection. This study aims to measure the change in troponin T-HS and CK-MB concentration at 6, 12, 24 and $48 \mathrm{~h}$ post-operatively (NCT03305094). Yellon and colleagues are recruiting 200 participants to study the effect of RIPC in type II diabetic patients undergoing CABG (NCT00397163). An important facet of this trial is the focus on understanding the RIPC-effect on diabetic CABG patients. PREP (Pediatric remote ischemic pre-conditioning prior to complex cardiac surgery), a randomised pilot study, recruited 53 participants and aims to assess if RIPC prior to heart surgery can improve the recovery of heart and brain after heart surgery in newborn babies with congenital heart disease (NCT01739088). This study aims to assess the feasibility for a larger randomized controlled study on paediatric RIPC. Deja and colleagues have completed a phase 2 trial on 134 participants who were presented with stable coronary artery disease referred for CABG (NCT01994707). The findings of the trial is yet to be reported. The study aimed to assess if RIPC changes the extent of apoptosis in human right atrial appendage and myocardial biopsy samples from LV harvested during cannulation for CABG. This study was performed under controlled experimental setting with the aim to establish if the RIPC phenomenon can be effectively used in clinical practice. RICARDO (Remote Ischemic Conditioning to Attenuate Myocardial Death and Improve Operative Outcome), a phase 2 clinical trial is currently recruiting an estimated 80 participants (NCT03363958). The interventional group will recipe RIPC $24 \mathrm{~h}$ prior to off-pump CABG and immediately prior to CABG. The RIPost group will receive intermittent lower limb ischemic conditioning within $60 \mathrm{~min}$ after the surgery, whereas control group will receive sham procedure perioperatively. The primary outcome measures of this study are postoperative myocardial necrosis at $72 \mathrm{~h}$ postoperatively and postoperative kidney injury at 7 days postoperatively.
Two large randomized controlled trials- CONDI-2 (Effect of RIPC on Clinical Outcomes in STEMI Patients Undergoing pPCI; NCT01857414) and ERIC-PPCI (Effect of Remote Ischemic Conditioning on clinical outcomes in STEMI patients undergoing PPCI; NCT02342522) are recruiting an estimated 2600 and 2000 participants respectively, randomized to RIPC or sham are nearing completion with harmonized primary endpoint of cardiac death and hospitalization for heart failure at 1 year in STEMI patients treated with PCI. ERIC-PPCI clinical trial includes two sub-studies: the biomarker sub-study will investigate enzymatic infarct size at 6 months and the cardiac magnetic resonance (CMR) sub-study will investigate infarct size at 6 months. RECOND (Reduction in Infarct Size by Remote Per-postconditioning in Patients With ST-Elevation Myocardial Infarction), a randomized trial assessing the effect of RIPC prior to PCI has completed study with 120 participants and will report on the changes in myocardial infarct size at 1 week determined by CMR (NCT02021760). RIC-STEMI (Remote ischemic conditioning in ST-elevated Myocardial Infarction as Adjuvant to Primary Angioplasty) has recruited 516 patients and aims to assess the effect of remote ischemic conditioning on cardiac-related death or hospitalization for heart failure rates up to 1 year during PCI in patients for STEMI (NCT02313961). CORICMI (Comprehensive Remote Ischemic Conditioning in Myocardial Infarction) is recruiting an estimated 200 participants to evaluate whether comprehensive remote ischemic perconditioning ( 5 cycles of $5 \mathrm{~min}$ inflation and 5 min deflation of cut on a lower limb prior to PCI), postconditioning ( 5 cycles of $5 \mathrm{~min}$ inflation and $5 \mathrm{~min}$ deflation of cuff on a lower limb immediately after PCI) and delayed ischemic conditioning (5 cycles of 5 min inflation and 5 min deflation of cuff on a lower limb daily on 2-28 days post $\mathrm{MI}$ ) as an adjunctive therapy in STEMI patients undergoing PCI can improve LVEF and remodeling at 30 days assessed by CMR with a minimum follow up time period of 1 year [172] (NCT03233919). DREAM (Daily Remote conditioning in Acute Myocardial Infarction), a UK based multicenter randomized controlled phase 2 trial has completed the study on estimated 90 participants (NCT01664611). This study focused on evaluating the effect of daily RIPC for 4 weeks post MI. The inclusion criteria included previous STEMI, successful PCI and LVEF $<45 \%$ on baseline echocardiography. The primary outcome data are obtained from baseline and 4 month CMR to assess the changes in LVEF. CRIC-RCT (Chronic Remote Ischemic Conditioning to Modify Post-MI Remodeling) is a multicenter clinical trial is currently recruiting an estimated 20 participants who are presented with STEMI involving LAD within $12 \mathrm{~h}$ of onset of the symptoms (NCT01817114). In this study, the effect of 4 cycles of 5 min-each ischemia and reperfusion of the right arm prior to PCI will be evaluated by assessing the changes in left 
ventricular end diastolic volume (LVEDV) at 28 days post PCI by MRI. This clinical trial excludes diabetic patients.

CONDI-PET (Effects of Remote Ischemic Conditioning on Myocardial Perfusion in Humans), a non-randomized phase 3 clinical trial in Denmark has completed the study on 50 participants with the primary objective of assessing the feasibility of using RIPC to treat ischemic heart disease and soon to report on changes in myocardial blood flow following intervention in these participants (NCT02230098). ERIC-LYSIS (Effect of Remote Ischemic Conditioning in Heart Attack Patients) has completed a randomized controlled trial on 519 participants to study whether remote ischemic conditioning in patients with STEMI can reduce myocardial tissue damage thereby preventing the onset of heart failure. The primary aim of this study was to measure serum CK$\mathrm{MB}$ and troponin T levels at different time points post thrombolysis to estimate the extent of myocardial damage during a heart attack (NCT02197117).

A phase 2 clinical trial is underway, studying the protective effect of RIPC on heart, kidney and brain in patients undergoing transcatheter aortic valve implantation (TAVI) on 100 recruited participants (NCT02080299). The primary endpoint of this study is peri-interventional myocardial injury by assessing the changes in troponin I serum concentrations at $72 \mathrm{~h}$ post intervention. We speculate that once these randomized trials are completed and the findings are reported, we will be in a better position to address the role of RIPC in protecting the heart from reperfusion injuries, and remodeling and whether this non-invasive technique merits phase 3 randomized trials before widely using in patient care.

\section{CHALLENGES OF TRANSLATING RIPC IN CLINICAL SETTINGS}

RIPC as a clinical strategy have been widely investigated in a large number of clinical trials with varied results. A systematic review and meta-analysis by Mcleod and colleagues suggested RIPC as a promising adjunctive treatment to PCI for the prevention of STEMIrelated reperfusion injury [173]. Table 1 includes some clinical trials on RIPC that did not render the expected cardioprotective outcome in CABG and PCI. Loss of translation in RIPC is a multi-faceted problem. Many of the trials were small cohort size, single-centered, had short follow-up period and lacked the power to investigate the end points such as death or hospitalization.

We have discussed the role of different proteins as circulating mediators of RIPC-mediated cardioprotection, however proteins in general have several significant therapeutic limitations. Protein therapeutics are expensive due to its high production cost limiting its patient access and clinical applications [174]. Chemical and physical instability of the therapeutic proteins is a critical issue and require further attention. Proteins can undergo degradation via various processes such as aggregation, denaturation, hydrolysis, oxidation and racemization. The route of administration of therapeutic proteins is also crucial to translate these humoral mediators of RIPC in clinical practice. Whilst intravenous, subcutaneous and intramuscular routes bypass the gastrointestinal enzymatic degradation, subcutaneous and intramuscular routes significantly reduces the bioavailability of these proteins compared to other routes [175]. A major concern for recombinant proteins as a therapeutic strategy is immune response during an unpredictable time scale which may reduce the efficacy of the therapeutic protein or rarely inactivate the native endogenous proteins [176]. Though this review paper has discussed the preclinical potential of the humoral proteins in reducing cardiac injuries from I/R injury, the mechanistic understanding and the pharmacodynamic and pharmacokinetic information of these potential candidates is very limited to translate it to clinical practice.

In addition, comorbidities such as hypercholesterolemia, diabetes, hypertension, left ventricular hypertrophy, obesity, age, sex, chronic kidney disease, comedication can limit the effectiveness of RIPC in clinical settings [177]. Hypercholesterolemia was the first comorbidity reported to impair the preconditioning effect. Tang and colleagues reported that, hypercholesterolemia impairs the upregulation of tetrahydrobiopterin (BH4) and reduces the nitric oxide synthase level [178]. Reduced bioavailable $\mathrm{NO}$ and increased peroxynitrite has been reported to reduce RIPC-induced cardioprotective effect through MMP-2 upregulation [179].

Diabetes macrovascular complications is associated with cardiovascular diseases. Yetgin and colleagues provided an indirect evidence for the failure of ischemic post-conditioning in diabetic patients undergoing PCI for AMI, where multiple balloon inflations as postconditioning stimulus failed to induce cardioprotective effect [180]. Jensen and colleagues found that, RIPC in non-diabetic healthy individuals, but not diabetic patients with neuropathy, release some undefined humoral factors and this humoral factor can increase myocardial ischemia tolerance in rabbits [181]. May be it is associated with the impaired cardioprotective pathways in diabetes such as PI3K-Akt, ERK1/2, K ATP dysfunction and reduced CGRP release [182].

Majority of the AMI patients present with hypertension [183]. Prodromal angina [184] and preinfarct angina [185] in hypertension patients did not show any protective effect of preconditioning. However, pre-infarction angina is a common feature in STEMI patients and it may confer cardioprotection [186]. It is possible that preexisting cardioprotection by pre-infarction angina limit the potential for further cardioprotection by RIPC.

Myocardium undergoes significant structural and functional changes with age. Previous studies reported 
significant reduction in ischemic tolerance [187] and prognosis following AMI [188]. A retrospective study reported that, pre-infarct angina was reduced in elderly patients [189]. Heinen and colleagues reported that bloodborne mediator of RIPC in human is affected by both age and sex [190]. They demonstrated that, RIPC plasma of male volunteers reduced infarct size in both young and old rats whereas RIPC plasma from old male volunteers failed to reduce infarct size in male rats. In contrast, RIPC plasma from both young female and old female volunteers was unable to reduce infarct size in male rats compared to control female blood plasma. As estrogen can produce cardioprotective effect [191], it is possible that estrogen receptor activation masks the cardioprotective effect of RIPC plasma.

Chronic kidney disease (CKD) is a common comorbidity in cardiovascular diseases [192] and is associated with impaired myocardial ischemic tolerance [193] [194]. However, a meta-analysis by Zhou and colleagues suggested that, RIPC reduced acute kidney injury in adults undergoing cardiac surgery [195]. Er and colleagues confirmed in RenPro Trial that RIPC stimulus also reduced contrast medium-induced acute kidney injury in high risk patients [196]. However, a meta-analysis by $\mathrm{Xie}$ and colleagues suggested that, whilst RIPC reduced post cardiac surgery troponin I and troponin $\mathrm{T}$ release, it could not reduce the incidence of AMI, AKI, and mortality [197]. However, this particular meta-analysis did not consider few confounding factors including whether the patients were on or off pump during the CABG, comorbidity such as diabetes or hyperlipidemia and use of specific medications. Chronic kidney disease does not seem likely to significantly impair the RIPC effect, but a larger multi-center trial is needed to confirm the findings.

Patients undergoing concurrent valve surgery with CABG experience larger surgical trauma compared to CABG surgery alone and are less likely to get the full benefit of RIPC [198]. RIPC mostly protect the heart from acute I/R injury, however, cardiac surgery-related injuries are not limited to I/R injury but are multi-factorial including inflammation, direct handling of the heart and coronary micro-embolism [198]. Hence, the efficacy of RIPC is linked with the complexity of the surgery.

The extent of preconditioning stimulus also modulates the cardioprotective effect of RIPC. Verouhis and colleagues also reported a neutral effect on MI size in anterior STEMI patients who underwent RIPC consisting of different numbers and cycles of leg ischemia and reperfusion before and after coronary reperfusion [199]. Too much of preconditioning stimulus may augment rather than attenuate the myocardial I/R injury [200].

Current guidelines recommend PCI to be performed within the first $12 \mathrm{~h}$ after the onset of the symptoms [201], and STEMI patients can obtain maximum benefit from myocardial reperfusion when done within the first $6 \mathrm{~h}$ after the onset of the symptoms [202]. However, whether RIPC follows the same time frame is unknown. Interestingly, area at risk (AAR) is critical to obtain the beneficial effect of RIPC. Infarct size is dependent on the AAR [203, 204] and current clinical evidence suggests that patients with larger AAR (greater than $40 \%$ of the LV volume) are more likely to obtain protection from RIPC [202]. Patients with small AAR develop smaller infarcts and are less likely to benefit from RIPC. Hence, it is crucial to accurately measure the infarct size and AAR. Imaging techniques such as cardiac MRI is emerging as a powerful imaging technique which is likely to address the challenges of measuring the accurate AAR and MI size and can be used in assessing alternate outcomes of cardioprotection [202].

Anesthesia is a confounder of cardioprotection by RIPC [205]. Interestingly, propofol anesthesia did not show significant differences in the primary outcome parameters including cardiovascular health, myocardial infarction, coronary revascularization, stroke and postoperative troponin I release in more than $90 \%$ of the CABG patients included in ERICCA trial [206]. However, perioperative anesthetic regimen was not defined in this study and in numerous cases, propofol was used in combination with opioids as the hypnotic agent. Another multicenter trial RIPHeart used propofol as the only narcotic agent while completely avoiding the use of any other volatile anesthetics [207]. Both ERICCA and RIPHeart trials used 4 cycles of $5 \mathrm{~min}$ arm occlusion and 5 min reperfusion rather than the established 3 cycles of $5 \mathrm{~min}$ intermittent occlusion and reperfusion and reported a neutral outcome in infarct size reduction in patients with anterior STEMI. Kottenberg and colleagues reported on a smaller single center trial demonstrating reduced postoperative Troponin I release only when anesthetic regimens without propofol was used [208]. A meta-analysis by Zangrillo and colleagues reported that volatile anesthesia, but not propofol, combined with RIPC reduced post-operative mortality rate in patients undergoing cardiac surgery [209]. It is still unclear how propofol anesthesia impairs the cardioprotective effect of RIPC but it is hypothesized that, propofol may be impairs the RIPC effect by abolishing the myocardial STAT5 phosphorylation [210] and/or by impairing the activation of the sensory fibers [211]. Interestingly, a multicenter trial in 240 patients undergoing cardiac surgery where thiopental was used for induction and sevoflurane for maintenance of general anesthesia reported that RIPC significantly reduced acute kidney injury (AKI) [123]. The results of this study have since been supported by a metaanalysis detecting statistically significant reduction in the incidence of post cardiac surgery AKI in patients receiving anesthetic regimen without propofol [212]. However, according to a meta-analysis by Zhou and colleagues alternative use of volatile anesthetics also attenuate the cardioprotection afforded by RIPC [213]. Propofol is the standard sedative agent used worldwide, hence completely avoiding propofol in the anesthetic regimen is limited to 
experimental settings but not to clinical settings which further complicates the translation of RIPC in clinical settings.

Co-medication can also act as a confounder of RIPC. CABG patients receive medications such as antidiabetic medicines, statins, angiotensin-converting enzyme inhibitors, angiotensin receptor blockers, beta-blockers, morphine, calcium antagonists-which can interfere with the RIPC effect [205]. These medications may facilitate cardioprotection, which may obscure the potential of RIPC-mediated cardioprotection.

It is essential to conduct clinical trials with strict inclusion requirements. In order to increase the power, many of the clinical trials recruit high number of patients and follow up post-operatively for a shorter period of time. A large multi-center clinical trial is essential to investigate why some RIPC clinical trials failed to improve clinical outcomes in CABG [214], [215], [216] and PCI [217] patients.

\section{CONCLUSIONS}

RIPC has provided an innovative non-invasive therapeutic strategy to prevent acute $\mathrm{I} / \mathrm{R}$ injury in susceptible organs and tissues with some variability. Non-invasive procedures such as using a blood pressure measuring cuff around the arm to achieve protection against I/R injury has facilitated its translation from bench to bedside. Though there are several clinical trials that did not show beneficial effects of RIPC, further mechanistic studies will help us understand the underlying cause of the failure of these studies. Optimal modality, site and duration of RIPC remains unclear. RIPC may nonetheless benefit children and adults undergoing certain elective surgeries where there is potential to improve clinical outcomes. Future insights into the control of circulating mediators of RIPC, including transcriptional regulation and secretion into the bloodstream will assist the development of pharmacologic approaches stimulating protective signaling pathways in target organs.

\section{Author contributions}

Billah $\mathrm{M}$ conceived and wrote the manuscript while Allahwala U, Ridiandries A, Mudaliar H, Dona A, Hunyor SN and Khachigian LM revised the manuscript critically with substantial intellectual input. Bhindi $\mathrm{R}$ supervised the development of the work, critically evaluated the manuscript with intellectual input. All authors approved the final version.

\section{ACKNOWLEDGMENTS}

The authors thank Tamanna Tabassum for illustrating the figure.

\section{CONFLICTS OF INTEREST}

The authors report no relationships that could be construed as a conflicts of interest.

\section{FUNDING}

The author received no financial support for the research, authorship and publication of this article.

\section{REFERENCES}

1. Ferdinandy P, Hausenloy DJ, Heusch G, Baxter GF, Schulz R. Interaction of risk factors, comorbidities, and comedications with ischemia/reperfusion injury and cardioprotection by preconditioning, postconditioning, and remote conditioning. Pharmacol Rev. 2014; 66:1142-74. https://doi.org/10.1124/pr.113.008300.

2. Jennings RB, Sommers HM, Smyth GA, Flack HA, Linn H. Myocardial necrosis induced by temporary occlusion of a coronary artery in the dog. Arch Pathol. 1960; 70:68-78.

3. Yellon DM, Hausenloy DJ. Myocardial reperfusion injury. N Engl J Med. 2007; 357:1121-35. https://doi.org/10.1056/NEJMra071667.

4. Murry CE, Jennings RB, Reimer KA. Preconditioning with ischemia: a delay of lethal cell injury in ischemic myocardium. Circulation. 1986; 74:1124-36.

5. Soncul H, Oz E, Kalaycioglu S. Role of ischemic preconditioning on ischemia-reperfusion injury of the lung. Chest. 1999; 115:1672-7.

6. Timsit MO, Gadet R, Ben Abdennebi H, Codas R, Petruzzo $\mathrm{P}$, Badet L. Renal ischemic preconditioning improves recovery of kidney function and decreases alpha-smooth muscle actin expression in a rat model. J Urol. 2008; 180:388-91. https://doi.org/10.1016/j.juro.2008.02.043.

7. Li JY, Gu X, Yin HZ, Zhou Y, Zhang WH, Qin YM. Protective effect of ischemic preconditioning on hepatic ischemia-reperfusion injury by advancing the expressive phase of survivin in rats. Hepatobiliary Pancreat Dis Int. 2008; 7:615-20.

8. Schoen M, Rotter R, Gierer P, Gradl G, Strauss U, Jonas L, Mittlmeier T, Vollmar B. Ischemic preconditioning prevents skeletal muscle tissue injury, but not nerve lesion upon tourniquet-induced ischemia. J Trauma. 2007; 63:788-97. https://doi.org/10.1097/01.ta.0000240440.85673.fc.

9. Erling Junior N, Montero EF, Sannomiya P, Poli-deFigueiredo LF. Local and remote ischemic preconditioning protect against intestinal ischemic/reperfusion injury after supraceliac aortic clamping. Clinics (Sao Paulo). 2013; 68:1548-54. https://doi.org/10.6061/clinics/2013(12)12.

10. Shi S, Yang W, Tu X, Chen C, Wang C. Ischemic preconditioning reduces ischemic brain injury by suppressing nuclear factor kappa B expression and 
neuronal apoptosis. Neural Regen Res. 2013; 8:633-8. https://doi.org/10.3969/j.issn.1673-5374.2013.07.007.

11. Perrault LP, Menasche P, Bel A, de Chaumaray T, Peynet J, Mondry A, Olivero P, Emanoil-Ravier R, Moalic JM. Ischemic preconditioning in cardiac surgery: a word of caution. J Thorac Cardiovasc Surg. 1996; 112:1378-86.

12. Przyklenk K, Bauer B, Ovize M, Kloner RA, Whittaker P. Regional ischemic 'preconditioning' protects remote virgin myocardium from subsequent sustained coronary occlusion. Circulation. 1993; 87:893-9.

13. Liauw SK, Rubin BB, Lindsay TF, Romaschin AD, Walker PM. Sequential ischemia/reperfusion results in contralateral skeletal muscle salvage. Am J Physiol. 1996; 270:H1407-13.

14. Kharbanda RK, Mortensen UM, White PA, Kristiansen SB, Schmidt MR, Hoschtitzky JA, Vogel M, Sorensen K, Redington AN, MacAllister R. Transient limb ischemia induces remote ischemic preconditioning in vivo. Circulation. 2002; 106:2881-3.

15. Schmidt MR, Smerup M, Konstantinov IE, Shimizu M, Li J, Cheung M, White PA, Kristiansen SB, Sorensen K, Dzavik V, Redington AN, Kharbanda RK. Intermittent peripheral tissue ischemia during coronary ischemia reduces myocardial infarction through a KATP-dependent mechanism: first demonstration of remote ischemic perconditioning. Am J Physiol Heart Circ Physiol. 2007; 292:H1883-90. https://doi.org/10.1152/ajpheart.00617.2006.

16. Kerendi F, Kin H, Halkos ME, Jiang R, Zatta AJ, Zhao ZQ, Guyton RA, Vinten-Johansen J. Remote postconditioning. Brief renal ischemia and reperfusion applied before coronary artery reperfusion reduces myocardial infarct size via endogenous activation of adenosine receptors. Basic Res Cardiol. 2005; 100:404-12. https://doi.org/10.1007/s00395-005-0539-2.

17. Pryds K, Nielsen RR, Jorsal A, Hansen MS, Ringgaard S, Refsgaard J, Kim WY, Petersen AK, Botker HE, Schmidt MR. Effect of long-term remote ischemic conditioning in patients with chronic ischemic heart failure. Basic Res Cardiol. 2017; 112:67. https://doi.org/10.1007/s00395-017-0658-6.

18. Pryds K, Kristiansen J, Neergaard-Petersen S, Nielsen RR, Schmidt MR, Refsgaard J, Kristensen SD, Botker HE, Hvas AM, Grove EL. Effect of longterm remote ischaemic conditioning on platelet function and fibrinolysis in patients with chronic ischaemic heart failure. Thromb Res. 2017; 153:40-6. https://doi.org/10.1016/j.thromres.2017.03.008.

19. Hausenloy DJ, Yellon DM. Remote ischaemic preconditioning: underlying mechanisms and clinical application. Cardiovasc Res. 2008; 79:377-86. https://doi.org/10.1093/cvr/cvn114.

20. Costa JF, Fontes-Carvalho R, Leite-Moreira AF. Myocardial remote ischemic preconditioning: from pathophysiology to clinical application. Rev Port Cardiol. 2013; 32:893-904. https://doi.org/10.1016/j.repc.2013.02.012.
21. Jones WK, Fan GC, Liao S, Zhang JM, Wang Y, Weintraub NL, Kranias EG, Schultz JE, Lorenz J, Ren X. Peripheral nociception associated with surgical incision elicits remote nonischemic cardioprotection via neurogenic activation of protein kinase C signaling. Circulation. 2009; 120:S1-9. https://doi.org/10.1161/CIRCULATIONAHA.108.843938.

22. Gho BC, Schoemaker RG, van den Doel MA, Duncker DJ, Verdouw PD. Myocardial protection by brief ischemia in noncardiac tissue. Circulation. 1996; 94:2193-200.

23. Weinbrenner C, Nelles M, Herzog N, Sarvary L, Strasser RH. Remote preconditioning by infrarenal occlusion of the aorta protects the heart from infarction: a newly identified non-neuronal but PKC-dependent pathway. Cardiovasc Res. 2002; 55:590-601.

24. Konstantinov IE, Li J, Cheung MM, Shimizu M, Stokoe J, Kharbanda RK, Redington AN. Remote ischemic preconditioning of the recipient reduces myocardial ischemia-reperfusion injury of the denervated donor heart via a Katp channel-dependent mechanism. Transplantation. 2005; 79:1691-5.

25. Dickson EW, Blehar DJ, Carraway RE, Heard SO, Steinberg G, Przyklenk K. Naloxone blocks transferred preconditioning in isolated rabbit hearts. J Mol Cell Cardiol. 2001; 33:1751-6. https://doi.org/10.1006/jmcc.2001.1436.

26. Dickson EW, Porcaro WA, Fenton RA, Heard SO, Reindhardt CP, Renzi FP, Przyklenk K. "Preconditioning at a distance" in the isolated rabbit heart. Acad Emerg Med. 2000; 7:311-7.

27. Dickson EW, Reinhardt CP, Renzi FP, Becker RC, Porcaro WA, Heard SO. Ischemic preconditioning may be transferable via whole blood transfusion: preliminary evidence. J Thromb Thrombolysis. 1999; 8:123-9.

28. Dickson EW, Lorbar M, Porcaro WA, Fenton RA, Reinhardt CP, Gysembergh A, Przyklenk K. Rabbit heart can be "preconditioned" via transfer of coronary effluent. Am J Physiol. 1999; 277:H2451-7.

29. Shimizu M, Tropak M, Diaz RJ, Suto F, Surendra H, Kuzmin E, Li J, Gross G, Wilson GJ, Callahan J, Redington AN. Transient limb ischaemia remotely preconditions through a humoral mechanism acting directly on the myocardium: evidence suggesting crossspecies protection. Clin Sci (Lond). 2009; 117:191-200. https://doi.org/10.1042/CS20080523.

30. Serejo FC, Rodrigues LF Jr, da Silva Tavares KC, de Carvalho AC, Nascimento JH. Cardioprotective properties of humoral factors released from rat hearts subject to ischemic preconditioning. J Cardiovasc Pharmacol. 2007; 49:214-20. https://doi.org/10.1097/FJC.0b013e3180325ad9.

31. Breivik L, Helgeland E, Aarnes EK, Mrdalj J, Jonassen AK. Remote postconditioning by humoral factors in effluent from ischemic preconditioned rat hearts is mediated via PI3K/Akt-dependent cell-survival signaling at reperfusion. Basic Res Cardiol. 2011; 106:135-45. https://doi.org/10.1007/s00395-010-0133-0. 
32. Lang SC, Elsasser A, Scheler C, Vetter S, Tiefenbacher CP, Kubler W, Katus HA, Vogt AM. Myocardial preconditioning and remote renal preconditioning--identifying a protective factor using proteomic methods? Basic Res Cardiol. 2006; 101:149-58. https://doi.org/10.1007/s00395-005-0565-0.

33. Chen G, Thakkar M, Robinson C, Dore S. Limb remote ischemic conditioning: mechanisms, anesthetics, and the potential for expanding therapeutic options. Front Neurol. 2018; 9:40. https://doi.org/10.3389/fneur.2018.00040.

34. Lim SY, Yellon DM, Hausenloy DJ. The neural and humoral pathways in remote limb ischemic preconditioning. Basic Res Cardiol. 2010; 105:651-5. https://doi.org/10.1007/s00395-010-0099-y.

35. Donato M, Buchholz B, Rodriguez M, Perez V, Inserte J, Garcia-Dorado D, Gelpi RJ. Role of the parasympathetic nervous system in cardioprotection by remote hindlimb ischaemic preconditioning. Exp Physiol. 2013; 98:425-34. https://doi.org/10.1113/expphysiol.2012.066217.

36. Ding YF, Zhang MM, He RR. Role of renal nerve in cardioprotection provided by renal ischemic preconditioning in anesthetized rabbits. Sheng Li Xue Bao. 2001; 53:7-12.

37. Liem DA, Verdouw PD, Ploeg H, Kazim S, Duncker DJ. Sites of action of adenosine in interorgan preconditioning of the heart. Am J Physiol Heart Circ Physiol. 2002; 283:H2937. https://doi.org/10.1152/ajpheart.01031.2001.

38. Dong JH, Liu YX, Ji ES, He RR. [Limb ischemic preconditioning reduces infarct size following myocardial ischemia-reperfusion in rats]. [Article in Chinese]. Sheng Li Xue Bao. 2004; 56:41-6.

39. Saxena P, Newman MA, Shehatha JS, Redington AN, Konstantinov IE. Remote ischemic conditioning: evolution of the concept, mechanisms, and clinical application. J Card Surg. 2010; 25:127-34. https://doi.org/10.1111/j.1540-8191.2009.00820.x.

40. Kharbanda RK, Peters M, Walton B, Kattenhorn M, Mullen M, Klein N, Vallance P, Deanfield J, MacAllister $\mathrm{R}$. Ischemic preconditioning prevents endothelial injury and systemic neutrophil activation during ischemia-reperfusion in humans in vivo. Circulation. 2001; 103:1624-30.

41. Konstantinov IE, Arab S, Kharbanda RK, Li J, Cheung MM, Cherepanov V, Downey GP, Liu PP, Cukerman E, Coles JG, Redington AN. The remote ischemic preconditioning stimulus modifies inflammatory gene expression in humans. Physiol Genomics. 2004; 19:143-50. https://doi.org/10.1152/physiolgenomics.00046.2004.

42. Peralta C, Fernandez L, Panes J, Prats N, Sans M, Pique JM, Gelpi E, Rosello-Catafau J. Preconditioning protects against systemic disorders associated with hepatic ischemiareperfusion through blockade of tumor necrosis factorinduced P-selectin up-regulation in the rat. Hepatology. 2001; 33:100-13. https://doi.org/10.1053/jhep.2001.20529.

43. Albrecht M, Zitta K, Bein B, Wennemuth G, Broch O, Renner J, Schuett T, Lauer F, Maahs D, Hummitzsch L, Cremer J, Zacharowski K, Meybohm P. Remote ischemic preconditioning regulates HIF-1alpha levels, apoptosis and inflammation in heart tissue of cardiosurgical patients: a pilot experimental study. Basic Res Cardiol. 2013; 108:314. https://doi.org/10.1007/s00395-012-0314-0.

44. Schmidt MR, Redington A, Botker HE. Remote conditioning the heart overview: translatability and mechanism. Br J Pharmacol. 2015; 172:1947-60. https://doi.org/10.1111/bph.12933.

45. Liu GS, Thornton J, Van Winkle DM, Stanley AW, Olsson RA, Downey JM. Protection against infarction afforded by preconditioning is mediated by $\mathrm{A} 1$ adenosine receptors in rabbit heart. Circulation. 1991; 84:350-6.

46. Auchampach JA, Gross GJ. Adenosine A1 receptors, KATP channels, and ischemic preconditioning in dogs. Am J Physiol. 1993; 264:H1327-36.

47. Yokota R, Fujiwara H, Miyamae M, Tanaka M, Yamasaki K, Itoh S, Koga K, Yabuuchi Y, Sasayama S. Transient adenosine infusion before ischemia and reperfusion protects against metabolic damage in pig hearts. Am J Physiol. 1995; 268:H1149-57.

48. Kleppisch T, Nelson MT. Adenosine activates ATP-sensitive potassium channels in arterial myocytes via $\mathrm{A} 2$ receptors and cAMP-dependent protein kinase. Proc Natl Acad Sci U S A. 1995; 92:12441-5.

49. Surendra H, Diaz RJ, Harvey K, Tropak M, Callahan J, Hinek A, Hossain T, Redington A, Wilson GJ. Interaction of delta and kappa opioid receptors with adenosine A1 receptors mediates cardioprotection by remote ischemic preconditioning. J Mol Cell Cardiol. 2013; 60:142-50. https://doi.org/10.1016/j.yjmcc.2013.04.010.

50. Li Y, Kloner RA. The cardioprotective effects of ischemic 'preconditioning' are not mediated by adenosine receptors in rat hearts. Circulation. 1993; 87:1642-8.

51. Grover GJ, Dzwonczyk S, Sleph PG, Sargent CA. The ATP-sensitive potassium channel blocker glibenclamide (glyburide) does not abolish preconditioning in isolated ischemic rat hearts. J Pharmacol Exp Ther. 1993; 265:559-64.

52. Takaoka A, Nakae I, Mitsunami K, Yabe T, Morikawa $\mathrm{S}$, Inubushi T, Kinoshita M. Renal ischemia/reperfusion remotely improves myocardial energy metabolism during myocardial ischemia via adenosine receptors in rabbits: effects of "remote preconditioning". J Am Coll Cardiol. 1999; 33:556-64.

53. Mahaffey KW, Puma JA, Barbagelata NA, DiCarli MF, Leesar MA, Browne KF, Eisenberg PR, Bolli R, Casas AC, Molina-Viamonte V, Orlandi C, Blevins R, Gibbons $\mathrm{RJ}$, et al. Adenosine as an adjunct to thrombolytic therapy for acute myocardial infarction: results of a multicenter, randomized, placebo-controlled trial: the Acute Myocardial Infarction STudy of ADenosine (AMISTAD) trial. J Am Coll Cardiol. 1999; 34:1711-20.

54. Ross AM, Gibbons RJ, Stone GW, Kloner RA, Alexander RW, and AMISTAD-II Investigators. A randomized, 
double-blinded, placebo-controlled multicenter trial of adenosine as an adjunct to reperfusion in the treatment of acute myocardial infarction (AMISTAD-II). J Am Coll Cardiol. 2005; 45:1775-80. https://doi.org/10.1016/j. jacc.2005.02.061.

55. Kloner RA, Forman MB, Gibbons RJ, Ross AM, Alexander RW, Stone GW. Impact of time to therapy and reperfusion modality on the efficacy of adenosine in acute myocardial infarction: the AMISTAD-2 trial. Eur Heart J. 2006; 27:2400-5. https://doi.org/10.1093/eurheartj/ehl094.

56. Oberkofler CE, Limani P, Jang JH, Rickenbacher A, Lehmann K, Raptis DA, Ungethuem U, Tian Y, Grabliauskaite K, Humar R, Graf R, Humar B, Clavien PA. Systemic protection through remote ischemic preconditioning is spread by plateletdependent signaling in mice. Hepatology. 2014; 60:1409-17. https://doi.org/10.1002/hep.27089.

57. Faleo G, Neto JS, Kohmoto J, Tomiyama K, Shimizu H, Takahashi T, Wang Y, Sugimoto R, Choi AM, Stolz DB, Carrieri G, McCurry KR, Murase N, et al. Carbon monoxide ameliorates renal cold ischemiareperfusion injury with an upregulation of vascular endothelial growth factor by activation of hypoxiainducible factor. Transplantation. 2008; 85:1833-40. https://doi.org/10.1097/TP.0b013e31817c6f63.

58. Furrer K, Rickenbacher A, Tian Y, Jochum W, Bittermann AG, Kach A, Humar B, Graf R, Moritz W, Clavien PA. Serotonin reverts age-related capillarization and failure of regeneration in the liver through a VEGF-dependent pathway. Proc Natl Acad Sci U S A. 2011; 108:2945-50. https://doi.org/10.1073/pnas.1012531108.

59. Parsa CJ, Kim J, Riel RU, Pascal LS, Thompson RB, Petrofski JA, Matsumoto A, Stamler JS, Koch WJ. Cardioprotective effects of erythropoietin in the reperfused ischemic heart: a potential role for cardiac fibroblasts. J Biol Chem. 2004; 279:20655-62. https://doi.org/10.1074/jbc.M314099200.

60. Riksen NP, Hausenloy DJ, Yellon DM. Erythropoietin: ready for prime-time cardioprotection. Trends Pharmacol Sci. 2008; 29:258-67. https://doi.org/10.1016/j.tips.2008.02.002.

61. Ferrario M, Massa M, Rosti V, Campanelli R, Ferlini M, Marinoni B, De Ferrari GM, Meli V, De Amici M, Repetto A, Verri A, Bramucci E, Tavazzi L. Early haemoglobinindependent increase of plasma erythropoietin levels in patients with acute myocardial infarction. Eur Heart J. 2007; 28:1805-13. https://doi.org/10.1093/eurheartj/ehm065.

62. Namiuchi S, Kagaya Y, Ohta J, Shiba N, Sugi M, Oikawa M, Kunii H, Yamao H, Komatsu N, Yui M, Tada H, Sakuma M, Watanabe J, et al. High serum erythropoietin level is associated with smaller infarct size in patients with acute myocardial infarction who undergo successful primary percutaneous coronary intervention. J Am Coll Cardiol. 2005; 45:1406-12. https://doi.org/10.1016/j.jacc.2005.01.043.

63. Nishihara M, Miura T, Miki T, Sakamoto J, Tanno M, Kobayashi H, Ikeda Y, Ohori K, Takahashi A, Shimamoto
K. Erythropoietin affords additional cardioprotection to preconditioned hearts by enhanced phosphorylation of glycogen synthase kinase-3 beta. Am J Physiol Heart Circ Physiol. 2006; 291:H748-55. https://doi.org/10.1152/ajpheart.00837.2005.

64. Calvillo L, Latini R, Kajstura J, Leri A, Anversa P, Ghezzi P, Salio M, Cerami A, Brines M. Recombinant human erythropoietin protects the myocardium from ischemia-reperfusion injury and promotes beneficial remodeling. Proc Natl Acad Sci U S A. 2003; 100:4802-6. https://doi.org/10.1073/pnas.0630444100.

65. Witthuhn BA, Quelle FW, Silvennoinen O, Yi T, Tang B, Miura O, Ihle JN. JAK2 associates with the erythropoietin receptor and is tyrosine phosphorylated and activated following stimulation with erythropoietin. Cell. 1993; 74:227-36.

66. Jacobs KM, Bhave SR, Ferraro DJ, Jaboin JJ, Hallahan DE, Thotala D. GSK-3beta: a bifunctional role in cell death pathways. Int J Cell Biol. 2012; 2012:930710. https://doi.org/10.1155/2012/930710.

67. Parsa CJ, Matsumoto A, Kim J, Riel RU, Pascal LS, Walton GB, Thompson RB, Petrofski JA, Annex BH, Stamler JS, Koch WJ. A novel protective effect of erythropoietin in the infarcted heart. J Clin Invest. 2003; 112:999-1007. https://doi.org/10.1172/JCI18200.

68. Tramontano AF, Muniyappa R, Black AD, Blendea MC, Cohen I, Deng L, Sowers JR, Cutaia MV, El-Sherif N. Erythropoietin protects cardiac myocytes from hypoxiainduced apoptosis through an Akt-dependent pathway. Biochem Biophys Res Commun. 2003; 308:990-4.

69. Oba T, Yasukawa H, Nagata T, Kyogoku S, Minami T, Nishihara M, Ohshima H, Mawatari K, Nohara S, Takahashi J, Sugi Y, Igata S, Iwamoto Y, et al. Renal nerve-mediated erythropoietin release confers cardioprotection during remote ischemic preconditioning. Circ J. 2015; 79:1557-67. https://doi.org/10.1253/circj.CJ-14-1171.

70. Diwan V, Jaggi AS, Singh M, Singh N, Singh D. Possible involvement of erythropoietin in remote renal preconditioning-induced cardioprotection in rats. J Cardiovasc Pharmacol. 2008; 51:126-30. https://doi.org/10.1097/FJC.0b013e31815d88c9.

71. van Niel G, D'Angelo G, Raposo G. Shedding light on the cell biology of extracellular vesicles. Nat Rev Mol Cell Biol. 2018; 19:213. https://doi.org/10.1038/nrm.2017.125.

72. Giricz Z, Varga ZV, Baranyai T, Sipos P, Paloczi K, Kittel A, Buzas EI, Ferdinandy P. Cardioprotection by remote ischemic preconditioning of the rat heart is mediated by extracellular vesicles. J Mol Cell Cardiol. 2014; 68:75-8. https://doi.org/10.1016/j.yjmcc.2014.01.004.

73. Vicencio JM, Yellon DM, Sivaraman V, Das D, Boi-Doku C, Arjun S, Zheng Y, Riquelme JA, Kearney J, Sharma V, Multhoff G, Hall AR, Davidson SM. Plasma exosomes protect the myocardium from ischemia-reperfusion injury. J Am Coll C ardiol. 2015; 65:1525-36. https://doi.org/10.1016/j. jacc.2015.02.026. 
74. Davidson SM, Riquelme JA, Zheng Y, Vicencio JM, Lavandero S, Yellon DM. Endothelial cells release cardioprotective exosomes that may contribute to ischaemic preconditioning. Sci Rep. 2018; 8:15885. https://doi.org/10.1038/s41598-018-34357-z.

75. Minghua W, Zhijian G, Chahua H, Qiang L, Minxuan X, Luqiao W, Weifang Z, Peng L, Biming Z, Lingling Y, Zhenzhen W, Jianqing X, Huihui B, et al. Plasma exosomes induced by remote ischaemic preconditioning attenuate myocardial ischaemia/reperfusion injury by transferring miR-24. Cell Death Dis. 2018; 9:320. https://doi.org/10.1038/s41419-018-0274-x.

76. Fischer S, Cabrera-Fuentes HA, Noll T, Preissner KT. Impact of extracellular RNA on endothelial barrier function. Cell Tissue Res. 2014; 355:635-45. https://doi.org/10.1007/s00441-014-1850-8.

77. Cabrera-Fuentes HA, Ruiz-Meana M, Simsekyilmaz S, Kostin S, Inserte J, Saffarzadeh M, Galuska SP, Vijayan V, Barba I, Barreto G, Fischer S, Lochnit G, Ilinskaya ON, et al. RNase 1 prevents the damaging interplay between extracellular RNA and tumour necrosis factor-alpha in cardiac ischaemia/reperfusion injury. Thromb Haemost. 2014; 112:1110-9. https://doi.org/10.1160/th14-08-0703.

78. Landre JB, Hewett PW, Olivot JM, Friedl P, Ko Y, Sachinidis A, Moenner M. Human endothelial cells selectively express large amounts of pancreatic-type ribonuclease (RNase 1). J Cell Biochem. 2002; 86:540-52. https://doi.org/10.1002/jcb.10234.

79. Fischer S, Nishio M, Dadkhahi S, Gansler J, Saffarzadeh M, Shibamiyama A, Kral N, Baal N, Koyama T, Deindl E, Preissner KT. Expression and localisation of vascular ribonucleases in endothelial cells. Thromb Haemost. 2011; 105:345-55. https://doi.org/10.1160/th10-06-0345.

80. Cabrera-Fuentes HA, Niemann B, Grieshaber P, Wollbrueck M, Gehron J, Preissner KT, Boning A. RNase1 as a potential mediator of remote ischaemic preconditioning for cardioprotectiondagger. Eur J Cardiothorac Surg. 2015; 48:732-7; discussion 7. https://doi.org/10.1093/ejcts/ezu519.

81. Hibert P, Prunier-Mirebeau D, Beseme O, Chwastyniak M, Tamareille S, Lamon D, Furber A, Pinet F, Prunier F. Apolipoprotein a-I is a potential mediator of remote ischemic preconditioning. PLoS One. 2013; 8:e77211. https://doi.org/10.1371/journal.pone.0077211.

82. Li J, Rohailla S, Gelber N, Rutka J, Sabah N, Gladstone RA, Wei C, Hu P, Kharbanda RK, Redington AN. MicroRNA-144 is a circulating effector of remote ischemic preconditioning. Basic Res Cardiol. 2014; 109:423. https:// doi.org/10.1007/s00395-014-0423-Z.

83. Zhang $\mathrm{X}$, Wang $\mathrm{X}$, Zhu $\mathrm{H}$, Zhu C, Wang Y, Pu WT, Jegga AG, Fan GC. Synergistic effects of the GATA4-mediated miR-144/451 cluster in protection against simulated ischemia/reperfusion-induced cardiomyocyte death. J Mol Cell Cardiol. 2010; 49:841-50. https://doi.org/10.1016/j.yjmcc.2010.08.007.
84. Minghua W, Zhijian G, Chahua H, Qiang L, Minxuan X, Luqiao W, Weifang Z, Peng L, Biming Z, Lingling Y, Zhenzhen W, Jianqing X, Huihui B, et al. Plasma exosomes induced by remote ischaemic preconditioning attenuate myocardial ischaemia/reperfusion injury by transferring miR-24. Cell Death Dis. 2018; 9:320. https://doi.org/10.1038/s41419-018-0274-X.

85. Rassaf T, Totzeck M, Hendgen-Cotta UB, Shiva S, Heusch G, Kelm M. Circulating nitrite contributes to cardioprotection by remote ischemic preconditioning. Circ Res. 2014; 114:160110. https://doi.org/10.1161/CIRCRESAHA.114.303822.

86. Nanduri J, Vaddi DR, Khan SA, Wang N, Makarenko V, Semenza GL, Prabhakar NR. HIF-1alpha activation by intermittent hypoxia requires NADPH oxidase stimulation by xanthine oxidase. PLoS One. 2015; 10:e119762. https://doi.org/10.1371/journal.pone.0119762.

87. Yellon DM, He Z, Khambata R, Ahluwalia A, Davidson SM. The GTN patch: a simple and effective new approach to cardioprotection? Basic Res Cardiol. 2018; 113:20. https://doi.org/10.1007/s00395-018-0681-2.

88. Hauerslev M, Mørk SR, Pryds K, Contractor H, Hansen J, Jespersen NR, Johnsen J, Heusch G, Kleinbongard P, Kharbanda R, Bøtker HE, Schmidt MR. Influence of long-term treatment with glyceryl trinitrate on remote ischemic conditioning. Am J Physiol Heart Circ Physiol. 2018; 315:H150-H8. https://doi.org/10.1152/ajpheart.00114.2018.

89. Kleinbongard P, Dejam A, Lauer T, Rassaf T, Schindler A, Picker O, Scheeren T, Godecke A, Schrader J, Schulz R, Heusch G, Schaub GA, Bryan NS, et al. Plasma nitrite reflects constitutive nitric oxide synthase activity in mammals. Free Radic Biol Med. 2003; 35:790-6.

90. Rassaf T, Heiss C, Hendgen-Cotta U, Balzer J, Matern S, Kleinbongard P, Lee A, Lauer T, Kelm M. Plasma nitrite reserve and endothelial function in the human forearm circulation. Free Radic Biol Med. 2006; 41:295-301. https://doi.org/10.1016/j.freeradbiomed.2006.04.006.

91. Hon YY, Sun H, Dejam A, Gladwin MT. Characterization of erythrocytic uptake and release and disposition pathways of nitrite, nitrate, methemoglobin, and iron-nitrosyl hemoglobin in the human circulation. Drug Metab Dispos. 2010; 38:1707-13. https://doi.org/10.1124/dmd.110.034355.

92. Schoemaker RG, van Heijningen CL. Bradykinin mediates cardiac preconditioning at a distance. Am J Physiol Heart Circ Physiol. 2000; 278:H1571-6.

93. Xiao L, Lu R, Hu CP, Deng HW, Li YJ. Delayed cardioprotection by intestinal preconditioning is mediated by calcitonin gene-related peptide. Eur J Pharmacol. 2001; 427:131-5.

94. Wharton J, Gulbenkian S. Peptides in the mammalian cardiovascular system. Experientia. 1987; 43:821-32.

95. Franco-Cereceda A, Henke H, Lundberg JM, Petermann JB, Hokfelt T, Fischer JA. Calcitonin gene-related peptide (CGRP) in capsaicin-sensitive substance P-immunoreactive 
sensory neurons in animals and man: distribution and release by capsaicin. Peptides. 1987; 8:399-410.

96. Cinca J, Rodriguez-Sinovas A, Anivarro I, Moure C, Tresanchez M, Soler-Soler J. Neurally mediated depressor hemodynamic response induced by intracoronary catheter balloon inflation in pigs. Cardiovasc Res. 2000; 46:198-206.

97. Kallner G. Release and effects of calcitonin gene-related peptide in myocardial ischaemia. Scand Cardiovasc J Suppl. 1998; 49:1-35.

98. Franco-Cereceda A. Calcitonin gene-related peptide and tachykinins in relation to local sensory control of cardiac contractility and coronary vascular tone. Acta Physiol Scand Suppl. 1988; 569:1-63.

99. Kress M, Zeilhofer HU. Capsaicin, protons and heat: new excitement about nociceptors. Trends Pharmacol Sci. 1999; $20: 112-8$.

100. Tang ZL, Dai W, Li YJ, Deng HW. Involvement of capsaicin-sensitive sensory nerves in early and delayed cardioprotection induced by a brief ischaemia of the small intestine. Naunyn Schmiedebergs Arch Pharmacol. 1999; 359:243-7.

101. Li YJ, Xiao ZS, Peng CF, Deng HW. Calcitonin generelated peptide-induced preconditioning protects against ischemia-reperfusion injury in isolated rat hearts. Eur J Pharmacol. 1996; 311:163-7.

102. Ferdinandy P, Csont T, Csonka C, Torok M, Dux M, Nemeth J, Horvath LI, Dux L, Szilvassy Z, Jancso G. Capsaicin-sensitive local sensory innervation is involved in pacing-induced preconditioning in rat hearts: role of nitric oxide and CGRP? Naunyn Schmiedebergs Arch Pharmacol. 1997; 356:356-63.

103. Lu R, Li YJ, Deng HW. Evidence for calcitonin generelated peptide-mediated ischemic preconditioning in the rat heart. Regul Pept. 1999; 82:53-7.

104. Li YJ, Peng J. The cardioprotection of calcitonin generelated peptide-mediated preconditioning. Eur J Pharmacol. 2002; 442:173-7.

105. Wolfrum S, Nienstedt J, Heidbreder M, Schneider K, Dominiak P, Dendorfer A. Calcitonin gene related peptide mediates cardioprotection by remote preconditioning. Regul Pept. 2005; 127:217-24. https://doi.org/10.1016/j.regpep.2004.12.008.

106. Peng CF, Li YJ, Deng HW, Xiong Y. The protective effects of ischemic and calcitonin gene-related peptideinduced preconditioning on myocardial injury by endothelin-1 in the isolated perfused rat heart. Life Sci. 1996; 59:1507-14.

107. Shimizu M, Saxena P, Konstantinov IE, Cherepanov V, Cheung MM, Wearden P, Zhangdong H, Schmidt M, Downey GP, Redington AN. Remote ischemic preconditioning decreases adhesion and selectively modifies functional responses of human neutrophils. J Surg Res. 2010; 158:15561. https://doi.org/10.1016/j.jss.2008.08.010.
108. Moore KW, de Waal Malefyt R, Coffman RL, O'Garra A. Interleukin-10 and the interleukin-10 receptor. Annu Rev Immunol. 2001; 19:683-765. https://doi.org/10.1146/annurev.immunol.19.1.683.

109. Manukyan MC, Alvernaz CH, Poynter JA, Wang Y, Brewster BD, Weil BR, Abarbanell AM, Herrmann JL, Crowe BJ, Keck AC, Meldrum DR. Interleukin-10 protects the ischemic heart from reperfusion injury via the STAT3 pathway. Surgery. 2011; 150:231-9. https://doi.org/10.1016/j.surg.2011.05.017.

110. Sharma S, Yang B, Xi X, Grotta JC, Aronowski J, Savitz SI. IL-10 directly protects cortical neurons by activating PI-3 kinase and STAT-3 pathways. Brain Res. 2011; 1373:18994. https://doi.org/10.1016/j.brainres.2010.11.096.

111. Cai ZP, Parajuli N, Zheng X, Becker L. Remote ischemic preconditioning confers late protection against myocardial ischemia-reperfusion injury in mice by upregulating interleukin-10. Basic Res Cardiol. 2012; 107:277. https://doi.org/10.1007/s00395-012-0277-1.

112. Parajuli N, Yuan Y, Zheng X, Bedja D, Cai ZP. Phosphatase PTEN is critically involved in post-myocardial infarction remodeling through the Akt/interleukin-10 signaling pathway. Basic Res Cardiol. 2012; 107:248. https://doi.org/10.1007/s00395-012-0248-6.

113. Staples KJ, Smallie T, Williams LM, Foey A, Burke B, Foxwell BM, Ziegler-Heitbrock L. IL-10 induces IL-10 in primary human monocyte-derived macrophages via the transcription factor Stat3. J Immunol. 2007; 178:4779-85.

114. Borthwick LA. The IL-1 cytokine family and its role in inflammation and fibrosis in the lung. Semin Immunopathol. 2016; 38:517-34. https://doi.org/10.1007/s00281-016-0559-z.

115. Rider P, Carmi Y, Voronov E, Apte RN. Interleukin1alpha. Semin Immunol. 2013; 25:430-8. https://doi.org/10.1016/j.smim.2013.10.005.

116. Lugrin J, Parapanov R, Rosenblatt-Velin N, Rignault-Clerc S, Feihl F, Waeber B, Muller O, Vergely C, Zeller M, Tardivel A, Schneider P, Pacher P, Liaudet L. Cutting edge: IL-1alpha is a crucial danger signal triggering acute myocardial inflammation during myocardial infarction. J Immunol. 2015; 194:499-503. https://doi.org/10.4049/jimmunol.1401948.

117. Grothusen C, Hagemann A, Attmann T, Braesen J, Broch O, Cremer J, Schoettler J. Impact of an interleukin-1 receptor antagonist and erythropoietin on experimental myocardial ischemia/reperfusion injury. ScientificWorldJournal. 2012; 2012:737585. https://doi.org/10.1100/2012/737585.

118. Mauro AG, Mezzaroma E, Torrado J, Kundur P, Joshi P, Stroud K, Quaini F, Lagrasta CA, Abbate A, Toldo S. Reduction of myocardial ischemia-reperfusion injury by inhibiting interleukin-1 alpha. J Cardiovasc Pharmacol. 2017; 69:156-60. https://doi.org/10.1097/FJC.0000000000000452.

119. Suzuki K, Murtuza B, Smolenski RT, Sammut IA, Suzuki N, Kaneda Y, Yacoub MH. Overexpression of interleukin-1 receptor antagonist provides cardioprotection against 
ischemia-reperfusion injury associated with reduction in apoptosis. Circulation. 2001; 104:I308-I3.

120. Gedik N, Kottenberg E, Thielmann M, Frey UH, Jakob H, Peters J, Heusch G, Kleinbongard P. Potential humoral mediators of remote ischemic preconditioning in patients undergoing surgical coronary revascularization. Sci Rep. 2017; 7:12660. https://doi.org/10.1038/s41598-017-12833-2.

121. Raja SG, Berg GA. Impact of off-pump coronary artery bypass surgery on systemic inflammation: current best available evidence. J Card Surg. 2007; 22:445-55. https://doi.org/10.1111/j.1540-8191.2007.00447.x.

122. Candilio L, Malik A, Hausenloy DJ. Protection of organs other than the heart by remote ischemic conditioning. J Cardiovasc Med (Hagerstown). 2013; 14:193-205. https://doi.org/10.2459/JCM.0b013e328359dd7b.

123. Zarbock A, Schmidt C, Van Aken H, Wempe C, Martens S, Zahn PK, Wolf B, Goebel U, Schwer CI, Rosenberger P, Haeberle H, Görlich D, Kellum JA, Meersch M, and RenalRIPC Investigators. Effect of remote ischemic preconditioning on kidney injury among high-risk patients undergoing cardiac surgery: a randomized clinical trial. JAMA. 2015; 313:2133-41. https://doi. org/10.1001/jama.2015.4189.

124. Libert C, Brouckaert P, Shaw A, Fiers W. Induction of interleukin 6 by human and murine recombinant interleukin 1 in mice. Eur J Immunol. 1990; 20:691-4. https://doi.org/10.1002/eji.1830200333.

125. Brown JM, White CW, Terada LS, Grosso MA, Shanley PF, Mulvin DW, Banerjee A, Whitman GJ, Harken AH, Repine JE. Interleukin 1 pretreatment decreases ischemia/reperfusion injury. Proc Natl Acad Sci U S A. 1990; 87:5026-30.

126. Maulik N, Engelman RM, Wei Z, Lu D, Rousou JA, Das DK. Interleukin-1 alpha preconditioning reduces myocardial ischemia reperfusion injury. Circulation. 1993; 88:II387-94.

127. Nogae C, Makino N, Hata T, Nogae I, Takahashi S, Suzuki $\mathrm{K}$, Taniguchi N, Yanaga T. Interleukin 1 alpha-induced expression of manganous superoxide dismutase reduces myocardial reperfusion injury in the rat. J Mol Cell Cardiol. 1995; 27:2091-9.

128. Askari AT, Unzek S, Popovic ZB, Goldman CK, Forudi F, Kiedrowski M, Rovner A, Ellis SG, Thomas JD, DiCorleto PE, Topol EJ, Penn MS. Effect of stromal-cell-derived factor 1 on stem-cell homing and tissue regeneration in ischaemic cardiomyopathy. Lancet. 2003; 362:697-703. https://doi.org/10.1016/S0140-6736(03)14232-8.

129. Hu X, Dai S, Wu WJ, Tan W, Zhu X, Mu J, Guo Y, Bolli R, Rokosh G. Stromal cell derived factor-1 alpha confers protection against myocardial ischemia/reperfusion injury: role of the cardiac stromal cell derived factor-1 alpha CXCR4 axis. Circulation. 2007; 116:654-63. https://doi.org/10.1161/CIRCULATIONAHA.106.672451.

130. Ceradini DJ, Kulkarni AR, Callaghan MJ, Tepper OM, Bastidas N, Kleinman ME, Capla JM, Galiano RD, Levine JP, Gurtner GC. Progenitor cell trafficking is regulated by hypoxic gradients through HIF-1 induction of SDF-1. Nat Med. 2004; 10:858-64. https://doi.org/10.1038/nm1075.

131. Davidson SM, Selvaraj P, He D, Boi-Doku C, Yellon RL, Vicencio JM, Yellon DM. Remote ischaemic preconditioning involves signalling through the SDF1alpha/CXCR4 signalling axis. Basic Res Cardiol. 2013; 108:377. https://doi.org/10.1007/s00395-013-0377-6.

132. Hepponstall M, Ignjatovic V, Binos S, Attard C, Karlaftis V, d'Udekem Y, Monagle P, Konstantinov IE. Remote ischemic preconditioning (RIPC) modifies the plasma proteome in children undergoing repair of tetralogy of fallot: a randomized controlled trial. PLoS One. 2015; 10:e0122778. https://doi.org/10.1371/journal.pone.0122778.

133. Misra P, Lebeche D, Ly H, Schwarzkopf M, Diaz G, Hajjar RJ, Schecter AD, Frangioni JV. Quantitation of CXCR4 expression in myocardial infarction using 99mTc-labeled SDF-1alpha. J Nucl Med. 2008; 49:963-9. https://doi.org/10.2967/jnumed.107.050054.

134. Jiang Q, Song P, Wang E, Li J, Hu S, Zhang H. Remote ischemic postconditioning enhances cell retention in the myocardium after intravenous administration of bone marrow mesenchymal stromal cells. J Mol Cell Cardiol. 2013; 56:1-7. https://doi.org/10.1016/j.yjmcc.2012.12.016.

135. Kamota T, Li TS, Morikage N, Murakami M, Ohshima M, Kubo M, Kobayashi T, Mikamo A, Ikeda Y, Matsuzaki M, Hamano K. Ischemic pre-conditioning enhances the mobilization and recruitment of bone marrow stem cells to protect against ischemia/reperfusion injury in the late phase. J Am Coll Cardiol. 2009; 53:1814-22. https://doi.org/10.1016/j.jacc.2009.02.015.

136. Huang C, Gu H, Zhang W, Manukyan MC, Shou W, Wang M. SDF-1/CXCR4 mediates acute protection of cardiac function through myocardial STAT3 signaling following global ischemia/reperfusion injury. Am J Physiol Heart Circ Physiol. 2011; 301:H1496-505. https://doi.org/10.1152/ajpheart.00365.2011.

137. Saxena A, Fish JE, White MD, Yu S, Smyth JW, Shaw RM, DiMaio JM, Srivastava D. Stromal cellderived factor-1alpha is cardioprotective after myocardial infarction. Circulation. 2008; 117:2224-31. https://doi.org/10.1161/CIRCULATIONAHA.107.694992.

138. Drucker DJ. Deciphering metabolic messages from the gut drives therapeutic innovation: the 2014 Banting Lecture. Diabetes. 2015; 64:317-26. https://doi.org/10.2337/db14-1514.

139. Ussher JR, Drucker DJ. Cardiovascular actions of incretin-based therapies. Circ Res. 2014; 114:1788-803. https://doi.org/10.1161/CIRCRESAHA.114.301958.

140. Holst JJ. The physiology of glucagon-like peptide 1. Physiol Rev. 2007; 87:1409-39. https://doi.org/10.1152/physrev.00034.2006.

141. Rocca AS, Brubaker PL. Role of the vagus nerve in mediating proximal nutrient-induced glucagon-like peptide-1 secretion. Endocrinology. 1999; 140:1687-94. https://doi.org/10.1210/endo.140.4.6643. 
142. Ban K, Noyan-Ashraf MH, Hoefer J, Bolz SS, Drucker DJ, Husain M. Cardioprotective and vasodilatory actions of glucagon-like peptide 1 receptor are mediated through both glucagon-like peptide 1 receptor-dependent and -independent pathways. Circulation. 2008; 117:2340-50. https://doi.org/10.1161/CIRCULATIONAHA.107.739938.

143. Ussher JR, Baggio LL, Campbell JE, Mulvihill EE, Kim M, Kabir MG, Cao X, Baranek BM, Stoffers DA, Seeley RJ, Drucker DJ. Inactivation of the cardiomyocyte glucagonlike peptide-1 receptor (GLP-1R) unmasks cardiomyocyteindependent GLP-1R-mediated cardioprotection. Mol Metab. 2014; 3:507-17. https://doi.org/10.1016/j.molmet.2014.04.009.

144. Bose AK, Mocanu MM, Carr RD, Brand CL, Yellon DM. Glucagon-like peptide 1 can directly protect the heart against ischemia/reperfusion injury. Diabetes. 2005; 54:146-51.

145. Bose AK, Mocanu MM, Carr RD, Yellon DM. Glucagon like peptide-1 is protective against myocardial ischemia/reperfusion injury when given either as a preconditioning mimetic or at reperfusion in an isolated rat heart model. Cardiovasc Drugs Ther. 2005; 19:9-11. https://doi.org/10.1007/s10557-005-6892-4.

146. Bose AK, Mocanu MM, Carr RD, Yellon DM. Myocardial ischaemia-reperfusion injury is attenuated by intact glucagon like peptide-1 (GLP-1) in the in vitro rat heart and may involve the p70s6K pathway. Cardiovasc Drugs Ther. 2007; 21:253-6. https://doi.org/10.1007/s10557-007-6030-6.

147. Lonborg J, Vejlstrup N, Kelbaek H, Botker HE, Kim WY, Mathiasen AB, Jorgensen E, Helqvist S, Saunamaki K, Clemmensen P, Holmvang L, Thuesen L, Krusell LR, et al. Exenatide reduces reperfusion injury in patients with ST-segment elevation myocardial infarction. Eur Heart J. 2012; 33:1491-9. https://doi.org/10.1093/eurheartj/ehr309.

148. Nikolaidis LA, Mankad S, Sokos GG, Miske G, Shah A, Elahi D, Shannon RP. Effects of glucagonlike peptide-1 in patients with acute myocardial infarction and left ventricular dysfunction after successful reperfusion. Circulation. 2004; 109:962-5. https://doi.org/10.1161/01.CIR.0000120505.91348.58.

149. Giblett JP, Clarke SJ, Dutka DP, Hoole SP. Glucagon-like peptide-1: a promising agent for cardioprotection during myocardial ischemia. JACC Basic Transl Sci. 2016; 1:26776. https://doi.or g/10.1016/j.jacbts.2016.03.011.

150. Basalay MV, Mastitskaya S, Mrochek A, Ackland GL, Del Arroyo AG, Sanchez J, Sjoquist PO, Pernow J, Gourine AV, Gourine A. Glucagon-like peptide-1 (GLP-1) mediates cardioprotection by remote ischaemic conditioning. Cardiovasc Res. 2016; 112:669-76. https://doi.org/10.1093/ cvr/cvw216.

151. Basalay M, Mastitskaya S, Mrochek A, Ackland GL, Arroyo AG, Sanchez J, Sjoquist PO, Pernow J, Gourine AV, Gourine A. Reply: Glucagon-like peptide-1 mediates cardioprotection by remote ischaemic conditioning. Cardiovasc Res. 2017; 113:13-4. https://doi.org/10.1093/cvr/cvw238.
152. Giblett JP, Hoole SP. Letter in response to glucagonlike peptide-1 mediates cardioprotection by remote ischaemic conditioning. Cardiovasc Res. 2017; 113:13. https://doi.org/10.1093/cvr/cvw237.

153. Pyke C, Heller RS, Kirk RK, Orskov C, Reedtz-Runge S, Kaastrup P, Hvelplund A, Bardram L, Calatayud D, Knudsen LB. GLP-1 receptor localization in monkey and human tissue: novel distribution revealed with extensively validated monoclonal antibody. Endocrinology. 2014; 155:1280-90. https://doi.org/10.1210/en.2013-1934.

154. Abu-Hamdah R, Rabiee A, Meneilly GS, Shannon RP, Andersen DK, Elahi D. Clinical review: the extrapancreatic effects of glucagon-like peptide-1 and related peptides. J Clin Endocrinol Metab. 2009; 94:1843-52. https://doi.org/10.1210/jc.2008-1296.

155. Ussher JR, Drucker DJ. Cardiovascular biology of the incretin system. Endocr Rev. 2012; 33:187-215. https://doi.org/10.1210/er.2011-1052.

156. McCormick LM, Hoole SP, White PA, Read PA, Axell RG, Clarke SJ, O'Sullivan M, West NEJ, Dutka DP. Pretreatment with glucagon-like Peptide-1 protects against ischemic left ventricular dysfunction and stunning without a detected difference in myocardial substrate utilization. JACC Cardiovasc Interv. 2015; 8:292-301. https://doi.org/10.1016/j.jcin.2014.09.014.

157. Read PA, Hoole SP, White PA, Khan FZ, O'Sullivan M, West NE, Dutka DP. A pilot study to assess whether glucagonlike peptide-1 protects the heart from ischemic dysfunction and attenuates stunning after coronary balloon occlusion in humans. Circ Cardiovasc Interv. 2011; 4:266-72. https://doi. org/10.1161/CIRCINTERVENTIONS.110.960476.

158. Hoole SP, Khan SN, White PA, Heck PM, Kharbanda RK, Densem CG, Clarke SC, Shapiro LM, Schofield PM, O’Sullivan M, Dutka DP. Remote ischaemic preconditioning does not attenuate ischaemic left ventricular dysfunction in humans. Eur J Heart Fail. 2009; 11:497-505. https://doi.org/10.1093/eurjhf/hfp040.

159. Kaelin WG Jr, Ratcliffe PJ. Oxygen sensing by metazoans: the central role of the HIF hydroxylase pathway. Mol Cell. 2008; 30:393-402. https://doi.org/10.1016/j.molcel.2008.04.009.

160. Olenchock BA, Moslehi J, Baik AH, Davidson SM, Williams J, Gibson WJ, Chakraborty AA, Pierce KA, Miller CM, Hanse EA, Kelekar A, Sullivan LB, Wagers AJ, et al. EGLN1 inhibition and rerouting of alpha-ketoglutarate suffice for remote ischemic protection. Cell. 2016; 164:884-95. https://doi.org/10.1016/j.cell.2016.02.006.

161. Frezza C, Zheng L, Tennant DA, Papkovsky DB, Hedley BA, Kalna G, Watson DG, Gottlieb E. Metabolic profiling of hypoxic cells revealed a catabolic signature required for cell survival. PLoS One. 2011; 6:e24411. https://doi.org/10.1371/journal.pone.0024411.

162. Chao de la Barca JM, Bakhta O, Kalakech H, Simard G, Tamareille S, Catros V, Callebert J, Gadras C, Tessier L, Reynier P, Prunier F, Mirebeau-Prunier D. Metabolic signature of remote ischemic preconditioning 
involving a cocktail of amino acids and biogenic amines. J Am Heart Assoc. 2016; 5:e003891. https://doi.org/10.1161/ JAHA.116.003891.

163. Ristagno G, Fries M, Brunelli L, Fumagalli F, Bagnati R, Russo I, Staszewsky L, Masson S, Li Volti G, Zappala A, Derwall M, Brucken A, Pastorelli R, et al. Early kynurenine pathway activation following cardiac arrest in rats, pigs, and humans. Resuscitation. 2013; 84:1604-10 https://doi.org/10.1016/j.resuscitation.2013.06.002.

164. Yin M, Zhong Z, Connor HD, Bunzendahl H, Finn WF, Rusyn I, Li X, Raleigh JA, Mason RP, Thurman RG. Protective effect of glycine on renal injury induced by ischemia-reperfusion in vivo. Am J Physiol Renal Physiol. 2002; 282:F417-23. https://doi.org/10.1152/ajprenal.00011.2001.

165. Zhong Z, Arteel GE, Connor HD, Yin M, Frankenberg MV, Stachlewitz RF, Raleigh JA, Mason RP, Thurman RG. Cyclosporin A increases hypoxia and free radical production in rat kidneys: prevention by dietary glycine. Am J Physiol. 1998; 275:F595-604.

166. Omasa M, Fukuse T, Toyokuni S, Mizutani Y, Yoshida H, Ikeyama K, Hasegawa S, Wada H. Glycine ameliorates lung reperfusion injury after cold preservation in an ex vivo rat lung model. Transplantation. 2003; 75:591-8. https://doi. org/10.1097/01.TP.0000053200.98125.14.

167. Ruiz-Meana M, Pina P, Garcia-Dorado D, RodriguezSinovas A, Barba I, Miro-Casas E, Mirabet M, SolerSoler J. Glycine protects cardiomyocytes against lethal reoxygenation injury by inhibiting mitochondrial permeability transition. J Physiol. 2004; 558:873-82. https://doi.org/10.1113/jphysiol.2004.068320.

168. Frank A, Rauen U, de Groot H. Protection by glycine against hypoxic injury of rat hepatocytes: inhibition of ion fluxes through nonspecific leaks. J Hepatol. 2000; 32:58-66.

169. Carini R, De Cesaris MG, Splendore R, Bagnati M, Bellomo G, Albano E. Alterations of $\mathrm{Na}(+)$ homeostasis in hepatocyte reoxygenation injury. Biochim Biophys Acta. 2000; 1500:297-305.

170. Rodriguez-Sinovas A, Garcia-Dorado D, Pina P, RuizMeana M, Soler-Soler J. Effect of sarcolemmal rupture on myocardial electrical impedance during oxygen deprivation. Am J Physiol Heart Circ Physiol. 2005; 288:H1396-403. https://doi.org/10.1152/ajpheart.00768.2004.

171. Jose Alburquerque-Bejar J, Barba I, Valls-Lacalle L, Ruiz-Meana M, Pecoraro M, Rodriguez-Sinovas A, Garcia-Dorado D. Remote ischemic conditioning provides humoural cross-species cardioprotection through glycine receptor activation. Cardiovasc Res. 2017; 113:52-60. https://doi.org/10.1093/cvr/cvw242.

172. Song L, Yan H, Zhou P, Zhao H, Liu C, Sheng Z, Tan Y, Yi C, Li J, Zhou J. Effect of comprehensive remote ischemic conditioning in anterior ST-elevation myocardial infarction undergoing primary percutaneous coronary intervention: design and rationale of the CORIC-MI randomized trial. Clin Cardiol. 2018; 41:997-1003. https://doi.org/10.1002/clc.22973.
173. McLeod SL, Iansavichene A, Cheskes S. Remote ischemic perconditioning to reduce reperfusion injury during acute ST-segment-elevation myocardial infarction: a systematic review and meta-analysis. J Am Heart Assoc. 2017; 6:e05522. https://doi.org/10.1161/JAHA.117.005522.

174. Kelley B. Industrialization of $\mathrm{mAb}$ production technology: the bioprocessing industry at a crossroads. MAbs. 2009; 1:443-52.

175. Zhao L, Ji P, Li Z, Roy P, Sahajwalla CG. The antibody drug absorption following subcutaneous or intramuscular administration and its mathematical description by coupling physiologically based absorption process with the conventional compartment pharmacokinetic model. J Clin Pharmacol. 2013; 53:314-25. https://doi.org/10.1002/jcph.4.

176. Schellekens H. Factors influencing the immunogenicity of therapeutic proteins. Nephrol Dial Transplant. 2005; 20:vi3-9. https://doi.org/10.1093/ndt/gfh1092.

177. McCafferty K, Forbes S, Thiemermann C, Yaqoob MM. The challenge of translating ischemic conditioning from animal models to humans: the role of comorbidities. Dis Model Mech. 2014; 7:1321-33. https://doi.org/10.1242/dmm.016741.

178. Tang XL, Takano H, Xuan YT, Sato H, Kodani E, Dawn B, Zhu Y, Shirk G, Wu WJ, Bolli R. Hypercholesterolemia abrogates late preconditioning via a tetrahydrobiopterin-dependent mechanism in conscious rabbits. Circulation. 2005; 112:2149 56. https://doi.org/10.1161/CIRCULATIONAHA.105.566190.

179. Giricz Z, Lalu MM, Csonka C, Bencsik P, Schulz R, Ferdinandy P. Hyperlipidemia attenuates the infarct sizelimiting effect of ischemic preconditioning: role of matrix metalloproteinase-2 inhibition. J Pharmacol Exp Ther. 2006; 316:154-61. https://doi.org/10.1124/jpet.105.091140.

180. Yetgin T, Magro M, Manintveld OC, Nauta ST, Cheng JM, den Uil CA, Simsek C, Hersbach F, van Domburg RT, Boersma E, Serruys PW, Duncker DJ, van Geuns RJ, et al. Impact of multiple balloon inflations during primary percutaneous coronary intervention on infarct size and longterm clinical outcomes in ST-segment elevation myocardial infarction: real-world postconditioning. Basic Res Cardiol. 2014; 109:403. https://doi.org/10.1007/s00395-014-0403-3.

181. Jensen RV, Zachara NE, Nielsen PH, Kimose HH, Kristiansen SB, Botker HE. Impact of O-GlcNAc on cardioprotection by remote ischaemic preconditioning in non-diabetic and diabetic patients. Cardiovasc Res. 2013; 97:369-78. https://doi.org/10.1093/cvr/cvs337.

182. Rana A, Goyal N, Ahlawat A, Jamwal S, Reddy BV, Sharma S. Mechanisms involved in attenuated cardio-protective role of ischemic preconditioning in metabolic disorders. Perfusion. 2015; 30:94-105. https://doi.org/10.1177/0267659114536760.

183. Wagner C, Ebner B, Tillack D, Strasser RH, Weinbrenner C. Cardioprotection by ischemic postconditioning is abrogated in hypertrophied myocardium of spontaneously hypertensive rats. J Cardiovasc Pharmacol. 2013; 61:35-41. https://doi.org/10.1097/FJC.0b013e3182760c4d.

184. Takeuchi T, Ishii Y, Kikuchi K, Hasebe N. Ischemic preconditioning effect of prodromal angina is attenuated in 
acute myocardial infarction patients with hypertensive left ventricular hypertrophy. Circ J. 2011; 75:1192-9.

185. Lorgis L, Gudjoncik A, Richard C, Mock L, Buffet P, Brunel P, Janin-Manificat L, Beer JC, Brunet D, Touzery C, Rochette L, Cottin Y, Zeller M. Pre-infarction angina and outcomes in non-ST-segment elevation myocardial infarction: data from the RICO survey. PLoS One. 2012; 7:e48513. https://doi.org/10.1371/journal.pone.0048513.

186. Heusch G. Nitroglycerin and delayed preconditioning in humans: yet another new mechanism for an old drug? Circulation. 2001; 103:2876-8.

187. Juhaszova M, Rabuel C, Zorov DB, Lakatta EG, Sollott SJ. Protection in the aged heart: preventing the heartbreak of old age? Cardiovasc Res. 2005; 66:233-44. https://doi.org/10.1016/j.cardiores.2004.12.020.

188. Tofler GH, Muller JE, Stone PH, Willich SN, Davis VG, Poole WK, Braunwald E. Factors leading to shorter survival after acute myocardial infarction in patients ages 65 to 75 years compared with younger patients. Am J Cardiol. 1988; 62:860-7.

189. Abete P, Ferrara N, Cacciatore F, Madrid A, Bianco S, Calabrese C, Napoli C, Scognamiglio P, Bollella O, Cioppa A, Longobardi G, Rengo F. Angina-induced protection against myocardial infarction in adult and elderly patients: a loss of preconditioning mechanism in the aging heart? J Am Coll Cardiol. 1997; 30:947-54.

190. Heinen A, Behmenburg F, Aytulun A, Dierkes M, Zerbin L, Kaisers W, Schaefer M, Meyer-Treschan T, Feit S, Bauer I, Hollmann MW, Huhn R. The release of cardioprotective humoral factors after remote ischemic preconditioning in humans is age- and sex-dependent. J Transl Med. 2018; 16:112. https://doi.org/10.1186/s12967-018-1480-0.

191. Booth EA, Obeid NR, Lucchesi BR. Activation of estrogen receptor-alpha protects the in vivo rabbit heart from ischemiareperfusion injury. Am J Physiol Heart Circ Physiol. 2005; 289:H2039-47. https://doi.org/10.1152/ajpheart.00479.2005.

192. Medi C, Montalescot G, Budaj A, Fox KA, López-Sendón J, FitzGerald G, Brieger DB, and GRACE Investigators. Reperfusion in patients with renal dysfunction after presentation with ST-segment elevation or left bundle branch block: GRACE (Global Registry of Acute Coronary Events). JACC Cardiovasc Interv. 2009; 2:26-33. https://doi.org/10.1016/j.jcin.2008.09.010.

193. Dikow R, Kihm LP, Zeier M, Kapitza J, Tornig J, Amann $\mathrm{K}$, Tiefenbacher C, Ritz E. Increased infarct size in uremic rats: reduced ischemia tolerance? J Am Soc Nephrol. 2004; 15:1530-6.

194. Byrne CJ, McCafferty K, Kieswich J, Harwood S, Andrikopoulos P, Raftery M, Thiemermann C, Yaqoob MM. Ischemic conditioning protects the uremic heart in a rodent model of myocardial infarction. Circulation. 2012; 125:125665. https://doi.org/10.1161/CIRCULATIONAHA.111.055392.

195. Zhou C, Bulluck H, Fang N, Li L, Hausenloy DJ. Age and surgical complexity impact on renoprotection by remote ischemic preconditioning during adult cardiac surgery: a meta analysis. Sci Rep. 2017; 7:215. https://doi.org/10.1038/s41598-017-00308-3.

196. Er F, Nia AM, Dopp H, Hellmich M, Dahlem KM, Caglayan E, Kubacki T, Benzing T, Erdmann E, Burst V, Gassanov N. Ischemic preconditioning for prevention of contrast medium-induced nephropathy: randomized pilot RenPro Trial (Renal Protection Trial). Circulation. 2012; 126:296-303. https://doi.org/10.1161/CIRCULATIONAHA.112.096370.

197. Xie J, Zhang X, Xu J, Zhang Z, Klingensmith NJ, Liu S, Pan C, Yang Y, Qiu H. Effect of remote ischemic preconditioning on outcomes in adult cardiac surgery: a systematic review and meta-analysis of randomized controlled studies. Anesth Analg. 2018; 127:30-8. https://doi.org/10.1213/ANE.0000000000002674.

198. Candilio L, Hausenloy D. Is there a role for ischaemic conditioning in cardiac surgery? F1000Res. 2017; 6:563. https://doi.org/10.12688/f1000research.10963.1.

199. Verouhis D, Sorensson P, Gourine A, Henareh L, Persson J, Saleh N, Settergren M, Sundqvist M, Tornvall P, Witt N, Bohm F, Pernow J. Effect of remote ischemic conditioning on infarct size in patients with anterior ST-elevation myocardial infarction. Am Heart J. 2016; 181:66-73. https://doi.org/10.1016/j.ahj.2016.08.004.

200. Whittaker P, Przyklenk K. From ischemic conditioning to 'hyperconditioning': clinical phenomenon and basic science opportunity. Dose Response. 2014; 12:650-63. https://doi.org/10.2203/dose-response.14-035.Whittaker.

201. Ovize M, Thibault H, Przyklenk K. Myocardial conditioning: opportunities for clinical translation. Circ Res. 2013; 113:43950. https://doi.org/10.1161/CIRCRESAHA.113.300764.

202. Ludman AJ, Yellon DM, Hausenloy DJ. Cardiac preconditioning for ischaemia: lost in translation. Dis Model Mech. 2010; 3:35-8. https://doi.org/10.1242/dmm.003855.

203. Reimer KA, Lowe JE, Rasmussen MM, Jennings RB. The wavefront phenomenon of ischemic cell death. 1 . Myocardial infarct size vs duration of coronary occlusion in dogs. Circulation. 1977; 56:786-94.

204. Reimer KA, Jennings RB. The "wavefront phenomenon" of myocardial ischemic cell death. II. Transmural progression of necrosis within the framework of ischemic bed size (myocardium at risk) and collateral flow. Lab Invest. 1979; 40:633-44.

205. Heusch G. Remote ischemic conditioning in cardiovascular surgery. J Cardiovasc Pharmacol Ther. 2017; 22:297-301. https://doi.org/10.1177/1074248416687874.

206. Hausenloy DJ, Candilio L, Laing C, Kunst G, Pepper J, Kolvekar S, Evans R, Robertson S, Knight R, Ariti C, Clayton T, Yellon DM, and ERICCA Trial Investigators. Effect of remote ischemic preconditioning on clinical outcomes in patients undergoing coronary artery bypass graft surgery (ERICCA): rationale and study design of a multi-centre randomized double-blinded controlled 
clinical trial. Clin Res Cardiol. 2012; 101:339-48. https://doi.org/10.1007/s00392-011-0397-x.

207. Meybohm P, Bein B, Brosteanu O, Cremer J, Gruenewald M, Stoppe C, Coburn M, Schaelte G, Boning A, Niemann B, Roesner J, Kletzin F, Strouhal U, et al. A multicenter trial of remote ischemic preconditioning for heart surgery. N Engl J Med. 2015; 373:1397-407. https://doi.org/10.1056/NEJMoa1413579.

208. Kottenberg E, Thielmann M, Bergmann L, Heine T, Jakob H, Heusch G, Peters J. Protection by remote ischemic preconditioning during coronary artery bypass graft surgery with isoflurane but not propofol - a clinical trial. Acta Anaesthesiol Scand. 2012; 56:30-8. https://doi.org/10.1111/j.1399-6576.2011.02585.x.

209. Zangrillo A, Musu M, Greco T, Di Prima AL, Matteazzi A, Testa V, Nardelli P, Febres D, Monaco F, Calabro MG, Ma J, Finco G, Landoni G. Additive effect on survival of anaesthetic cardiac protection and remote ischemic preconditioning in cardiac surgery: a bayesian network metaanalysis of randomized trials. PLoS One. 2015; 10:e134264. https://doi.org/10.1371/journal.pone.0134264.

210. Kottenberg E, Musiolik J, Thielmann M, Jakob H, Peters J, Heusch G. Interference of propofol with signal transducer and activator of transcription 5 activation and cardioprotection by remote ischemic preconditioning during coronary artery bypass grafting. J Thorac Cardiovasc Surg. 2014; 147:37682. https://doi.org/10.1016/j.jtcvs.2013.01.005.

211. Neukom L, Vastani N, Seifert B, Spahn DR, Maurer K. Propofol decreases the axonal excitability in rat primary sensory afferents. Life Sci. 2012; 90:343-50. https://doi.org/10.1016/j.lfs.2011.12.007.

212. Pierce B, Bole I, Patel V, Brown DL. Clinical outcomes of remote ischemic preconditioning prior to cardiac surgery: a meta-analysis of randomized controlled trials. J Am Heart Assoc. 2017; 6:e004666. https://doi.org/10.1161/ JAHA.116.004666.

213. Zhou C, Liu Y, Yao Y, Zhou S, Fang N, Wang W, Li L. beta-blockers and volatile anesthetics may attenuate cardioprotection by remote preconditioning in adult cardiac surgery: a meta-analysis of 15 randomized trials. J Cardiothorac Vasc Anesth. 2013; 27:305-11. https://doi.org/10.1053/j.jvca.2012.09.028.

214. Lucchinetti E, Bestmann L, Feng J, Freidank H, Clanachan AS, Finegan BA, Zaugg M. Remote ischemic preconditioning applied during isoflurane inhalation provides no benefit to the myocardium of patients undergoing on-pump coronary artery bypass graft surgery: lack of synergy or evidence of antagonism in cardioprotection? Anesthesiology. 2012; 116:296-310. https://doi.org/10.1097/ALN.0b013e318242349a.

215. Hausenloy DJ, Candilio L, Evans R, Ariti C, Jenkins DP, Kolvekar S, Knight R, Kunst G, Laing C, Nicholas J, Pepper J, Robertson S, Xenou M, et al. Remote ischemic preconditioning and outcomes of cardiac surgery. N Engl J Med. 2015; 373:1408-17. https://doi.org/10.1056/NEJMoa1413534.

216. Krogstad LE, Slagsvold KH, Wahba A. Remote ischemic preconditioning and incidence of postoperative atrial fibrillation. Scand Cardiovasc J. 2015; 49:117-22. https://doi.org/10.3109/14017431.2015.1010565.

217. Prasad A, Gossl M, Hoyt J, Lennon RJ, Polk L, Simari R, Holmes DR Jr, Rihal CS, Lerman A. Remote ischemic preconditioning immediately before percutaneous coronary intervention does not impact myocardial necrosis, inflammatory response, and circulating endothelial progenitor cell counts: a single center randomized sham controlled trial. Catheter Cardiovasc Interv. 2013; 81:930 6. https://doi.org/10.1002/ccd.24443.

218. Hong DM, Jeon Y, Lee CS, Kim HJ, Lee JM, Bahk JH, Kim $\mathrm{KB}$, Hwang HY. Effects of remote ischemic preconditioning with postconditioning in patients undergoing off-pump coronary artery bypass surgery--randomized controlled trial. Circ J. 2012; 76:884-90.

219. Hausenloy DJ, Mwamure PK, Venugopal V, Harris J, Barnard M, Grundy E, Ashley E, Vichare S, Di Salvo C, Kolvekar S, Hayward M, Keogh B, MacAllister RJ, et al. Effect of remote ischaemic preconditioning on myocardial injury in patients undergoing coronary artery bypass graft surgery: a randomised controlled trial. Lancet. 2007; 370:575-9. https://doi.org/10.1016/S0140-6736(07)61296-3.

220. Candilio L, Malik A, Ariti C, Barnard M, Di Salvo C, Lawrence D, Hayward M, Yap J, Roberts N, Sheikh A, Kolvekar S, Hausenloy DJ, Yellon DM. Effect of remote ischaemic preconditioning on clinical outcomes in patients undergoing cardiac bypass surgery: a randomised controlled clinical trial. Heart. 2015; 101:185-92. https://doi.org/10.1136/heartjnl-2014-306178.

221. Venugopal V, Hausenloy DJ, Ludman A, Di Salvo C, Kolvekar S, Yap J, Lawrence D, Bognolo J, Yellon DM. Remote ischaemic preconditioning reduces myocardial injury in patients undergoing cardiac surgery with coldblood cardioplegia: a randomised controlled trial. Heart. 2009; 95:1567-71. https://doi.org/10.1136/hrt.2008.155770.

222. Hong DM, Lee EH, Kim HJ, Min JJ, Chin JH, Choi DK, Bahk JH, Sim JY, Choi IC, Jeon Y. Does remote ischaemic preconditioning with postconditioning improve clinical outcomes of patients undergoing cardiac surgery? Remote Ischaemic Preconditioning with Postconditioning Outcome Trial. Eur Heart J. 2014; 35:176-83. https://doi.org/10.1093/eurheartj/eht346.

223. Pryds K, Terkelsen CJ, Sloth AD, Munk K, Nielsen SS, Schmidt MR, Bøtker HE, and CONDI Investigators. Remote ischaemic conditioning and healthcare system delay in patients with ST-segment elevation myocardial infarction. Heart. 2016; 102:1023-8. https://doi.org/10.1136/ heartjnl-2015-308980.

224. Sloth AD, Schmidt MR, Munk K, Schmidt M, Pedersen L, Sørensen HT, Bøt ker HE, and CONDI 
Investigators. Impact of cardiovascular risk factors and medication use on the efficacy of remote ischaemic conditioning: post hoc subgroup analysis of a randomised controlled trial. BMJ Open. 2015; 5:e06923. https://doi.org/10.1136/bmjopen-2014-006923.

225. Pryds K, Bøttcher M, Sloth AD, Munk K, Rahbek Schmidt $\mathrm{M}$, Bøtker HE, and CONDI Investigators. Influence of preinfarction angina and coronary collateral blood flow on the efficacy of remote ischaemic conditioning in patients with ST segment elevation myocardial infarction: post hoc subgroup analysis of a randomised controlled trial. BMJ Open. 2016; 6:e013314. https://doi.org/10.1136/ bmjopen-2016-013314.

226. Botker HE, Kharbanda R, Schmidt MR, Bottcher M, Kaltoft AK, Terkelsen CJ, Munk K, Andersen NH, Hansen TM, Trautner S, Lassen JF, Christiansen EH, Krusell LR, et al. Remote ischaemic conditioning before hospital admission, as a complement to angioplasty, and effect on myocardial salvage in patients with acute myocardial infarction: a randomised trial. Lancet. 2010; 375:727-34. https://doi.org/10.1016/S0140-6736(09)62001-8.

227. McClanahan TB, Nao BS, Woke LJ, Martin BJ, Mertz TE, Gallagher GP. Brief renal occlusion and reperfusion reduces myocardial infarct size in rabbits. FASEB J. 1993; 7.

228. Verdouw PD, Gho BC, Koning MM, Schoemaker RG, Duncker DJ. Cardioprotection by ischemic and nonischemic myocardial stress and ischemia in remote organs. Implications for the concept of ischemic preconditioning. Ann N Y Acad Sci. 1996; 793:27-42.

229. Pell TJ, Baxter GF, Yellon DM, Drew GM. Renal ischemia preconditions myocardium: role of adenosine receptors and ATP-sensitive potassium channels. Am J Physiol. 1998; 275:H1542-7.

230. Diwan V, Kant R, Jaggi AS, Singh N, Singh D. Signal mechanism activated by erythropoietin preconditioning and remote renal preconditioning-induced cardioprotection. Mol Cell Biochem. 2008; 315:195-201. https://doi.org/10.1007/s11010-008-9808-3.

231. Singh D, Chopra K. Evidence of the role of angiotensin AT(1) receptors in remote renal preconditioning of myocardium. Methods Find Exp Clin Pharmacol. 2004; 26:117-22.

232. Kant R, Diwan V, Jaggi AS, Singh N, Singh D. Remote renal preconditioning-induced cardioprotection: a key role of hypoxia inducible factor-prolyl 4-hydroxylases. Mol Cell Biochem. 2008; 312:25-31. https://doi.org/10.1007/s11010-008-9717-5.

233. Patel HH, Moore J, Hsu AK, Gross GJ. Cardioprotection at a distance: mesenteric artery occlusion protects the myocardium via an opioid sensitive mechanism. J Mol Cell Cardiol. 2002; 34:1317-23.

234. Heidbreder M, Naumann A, Tempel K, Dominiak P, Dendorfer A. Remote vs. ischaemic preconditioning: the differential role of mitogen-activated protein kinase pathways. Cardiovasc Res. 2008; 78:108-15. https://doi.org/10.1093/cvr/cvm114.

235. Ates E, Genc E, Erkasap N, Erkasap S, Akman S, Firat P, Emre S, Kiper H. Renal protection by brief liver ischemia in rats. Transplantation. 2002; 74:1247-51. https://doi.org/10.1097/01.TP.0000032752.61372.36.

236. Brzozowski T, Konturek PC, Pajdo R, Kwiecien S, Sliwowski Z, Drozdowicz D, Ptak-Belowska A, Pawlik M, Konturek SJ, Pawlik WW, Hahn GG. Importance of brain-gut axis in the gastroprotection induced by gastric and remote preconditioning. J Physiol Pharmacol. 2004; 55:165-77.

237. Tapuria N, Junnarkar SP, Dutt N, Abu-Amara M, Fuller B, Seifalian AM, Davidson BR. Effect of remote ischemic preconditioning on hepatic microcirculation and function in a rat model of hepatic ischemia reperfusion injury. HPB (Oxford). 2009; 11:108-17. https://doi.org/10.1111/j.1477-2574.2009.00006.x.

238. Oxman T, Arad M, Klein R, Avazov N, Rabinowitz B. Limb ischemia preconditions the heart against reperfusion tachyarrhythmia. Am J Physiol. 1997; 273:H1707-12.

239. Birnbaum Y, Hale SL, Kloner RA. Ischemic preconditioning at a distance: reduction of myocardial infarct size by partial reduction of blood supply combined with rapid stimulation of the gastrocnemius muscle in the rabbit. Circulation. 1997; 96:1641-6.

240. Gunaydin B, Cakici I, Soncul H, Kalaycioglu S, Cevik C, Sancak B, Kanzik I, Karadenizli Y. Does remote organ ischaemia trigger cardiac preconditioning during coronary artery surgery? Pharmacol Res. 2000; 41:493-6 https://doi.org/10.1006/phrs.1999.0611.

241. Xia Z, Herijgers P, Nishida T, Ozaki S, Wouters P, Flameng W. Remote preconditioning lessens the deterioration of pulmonary function after repeated coronary artery occlusion and reperfusion in sheep. Can J Anaesth. 2003; 50:481-8. https://doi.org/10.1007/BF03021061.

242. Addison PD, Neligan PC, Ashrafpour H, Khan A, Zhong A, Moses M, Forrest CR, Pang CY. Noninvasive remote ischemic preconditioning for global protection of skeletal muscle against infarction. Am J Physiol Heart Circ Physiol. 2003; 285:H1435-43. https://doi.org/10.1152/ajpheart.00106.2003.

243. Kuntscher MV, Kastell T, Engel H, Gebhard MM, Heitmann C, Germann G. Late remote ischemic preconditioning in rat muscle and adipocutaneous flap models. Ann Plast Surg. 2003; 51:84-90. https://doi.org/10.1097/01.SAP.0000054186.10681.E2.

244. Kuntscher MV, Kastell T, Sauerbier M, Nobiling R, Gebhard MM, Germann G. Acute remote ischemic preconditioning on a rat cremasteric muscle flap model. Microsurgery. 2002; 22:221-6. https://doi.org/10.1002/micr.10041.

245. Kuntscher MV, Schirmbeck EU, Menke H, Klar E, Gebhard MM, Germann G. Ischemic preconditioning by brief extremity ischemia before flap ischemia in a rat model. Plast Reconstr Surg. 2002; 109:2398-404. 
246. Moses MA, Addison PD, Neligan PC, Ashrafpour H, Huang N, Zair M, Rassuli A, Forrest CR, Grover GJ, Pang CY. Mitochondrial KATP channels in hindlimb remote ischemic preconditioning of skeletal muscle against infarction. Am J Physiol Heart Circ Physiol. 2005; 288:H559-67. https://doi. org/10.1152/ajpheart.00845.2004.

247. Wang WZ, Stepheson LL, Fang XH, Khiabani KT, Zamboni WA. Ischemic preconditioninginduced microvascular protection at a distance. J Reconstr Microsurg. 2004; 20:175-81. https://doi.org/10.1055/s-2004-820775.

248. Harkin DW, Barros D'Sa AA, McCallion K, Hoper M, Campbell FC. Ischemic preconditioning before lower limb ischemia--reperfusion protects against acute lung injury. $\mathrm{J}$ Vasc Surg. 2002; 35:1264-73.

249. Li G, Labruto F, Sirsjo A, Chen F, Vaage J, Valen G. Myocardial protection by remote preconditioning: the role of nuclear factor kappa-B p105 and inducible nitric oxide synthase. Eur J Cardiothorac Surg. 2004; 26:968-73. https://doi.org/10.1016/j.ejcts.2004.06.015.

250. Chen XG, Wu BY, Wang JK, Bai T. [Mechanism of the protective effects of noninvasive limbs preconditioning on myocardial ischemia-reperfusion injury]. [Article in Chinese]. Chin Med J (Engl). 2005; 118:1723-7.

251. Chen YS, Chien CT, Ma MC, Tseng YZ, Lin FY, Wang SS, Chen CF. Protection "outside the box" (skeletal remote preconditioning) in rat model is triggered by free radical pathway. J Surg Res. 2005; 126:92-101. https://doi.org/10.1016/j.jss.2005.01.007.

252. Loukogeorgakis SP, Panagiotidou AT, Broadhead MW, Donald A, Deanfield JE, MacAllister RJ. Remote ischemic preconditioning provides early and late protection against endothelial ischemia-reperfusion injury in humans: role of the autonomic nervous system. J Am Coll Cardiol. 2005; 46:450-6. https://doi.org/10.1016/j.jacc.2005.04.044.

253. Waldow T, Alexiou K, Witt W, Albrecht S, Wagner F, Knaut M, Matschke K. Protection against acute porcine lung ischemia/reperfusion injury by systemic preconditioning via hind limb ischemia. Transpl Int. 2005; 18:198-205. https://doi.org/10.1111/j.1432-2277.2004.00005.x.

254. Kristiansen SB, Henning O, Kharbanda RK, Nielsen-Kudsk JE, Schmidt MR, Redington AN, Nielsen TT, Botker HE. Remote preconditioning reduces ischemic injury in the explanted heart by a KATP channel-dependent mechanism. Am J Physiol Heart Circ Physiol. 2005; 288:H1252-6. https://doi.org/10.1152/ajpheart.00207.2004.

255. Zhang SZ, Wang NF, Xu J, Gao Q, Lin GH, Bruce IC, Xia Q. Kappa-opioid receptors mediate cardioprotection by remote preconditioning. Anesthesiology. 2006; 105:550-6.

256. Dave KR, Saul I, Prado R, Busto R, Perez-Pinzon MA. Remote organ ischemic preconditioning protect brain from ischemic damage following asphyxial cardiac arrest. Neurosci Lett. 2006; 404:170-5. https://doi.org/10.1016/j.neulet.2006.05.037.

257. Kanoria S, Jalan R, Davies NA, Seifalian AM, Williams $\mathrm{R}$, Davidson BR. Remote ischaemic preconditioning of the hind limb reduces experimental liver warm ischaemia-reperfusion injury. Br J Surg. 2006; 93:762-8 https://doi.org/10.1002/bjs.5331.

258. Lai IR, Chang KJ, Chen CF, Tsai HW. Transient limb ischemia induces remote preconditioning in liver among rats: the protective role of heme oxygenase-1. Transplantation. 2006; 81:1311-7. https://doi.org/10.1097/01.tp.0000203555.14546.63.

259. Cheung MM, Kharbanda RK, Konstantinov IE, Shimizu M, Frndova H, Li J, Holtby HM, Cox PN, Smallhorn JF, Van Arsdell GS, Redington AN. Randomized controlled trial of the effects of remote ischemic preconditioning on children undergoing cardiac surgery: first clinical application in humans. J Am Coll Cardiol. 2006; 47:2277-82. https://doi.org/10.1016/j.jacc.2006.01.066.

260. Mudaliar H, Rayner B, Billah M, Kapoor N, Lay W, Dona A, Bhindi R. Remote ischemic preconditioning attenuates EGR-1 expression following myocardial ischemia reperfusion injury through activation of the JAK-STAT pathway. Int J Cardiol. 2017; 228:729-41. https://doi.org/10.1016/j.ijcard.2016.11.198. 